\title{
ESTUDO COMPARATIVO DA FIXAÇÃO E INTEGRAÇÃO DE ENXERTOS ÓSSEOS "ONLAY"COM O USO DE N-BUTIL-2-CIANOCRILATO OU PARAFUSO DE TITÂNIO. ESTUDO HISTOLÓGICO, IMUNOHISTOQUÍMICO E TOMOGRÁFICO EM COELHOS.
}

Dissertação apresentada à Faculdade de Odontologia de Ribeirão Preto - USP, como parte dos requisitos para obtenção do título de Mestre em Cirurgia e Traumatologia Buco-Maxilo-Facial.

Orientador: Prof. Dr. Luiz Antônio Salata

Ribeirão Preto 
Autorizo a reprodução e divulgação total ou parcial da presente obra, por qualquer meio convencional ou eletrônico, para fins de estudo e pesquisa, desde que citada a fonte.

Oliveira Neto, Patrício José

Estudo comparativo da fixação e integração de enxertos ósseos "onlay" com o uso de n-Butil-2-Cianocrilato ou parafuso de titânio. Estudo histológico, imunohistoquímico e tomográfico em Coelhos. Ribeirão Preto, 2010.

55p. : il. ; $30 \mathrm{~cm}$

Dissertação de Mestrado, apresentada à Faculdade de Odontologia de Ribeirão Preto/USP. Área de concentração: Cirurgia e Traumatologia Buco-Maxilo-Facial.

Orientador: Salata, Luiz Antônio.

1. Cianocrilato. 2. Enxerto Ósseo Onlay. 3. Reparo Ósseo. 4. Imunohistoquímica. 5. Avaliação Tomográfica. 6. Avaliação Histológica. 7. Fixação de enxertos ósseos. 


\section{ESTUDO COMPARATIVO DA FIXAÇÃO E INTEGRAÇÃO DE ENXERTOS ÓSSEOS "ONLAY"COM O USO DE N-BUTIL-2-CIANOCRILATO OU PARAFUSO DE TITÂNIO. ESTUDO HISTOLÓGICO, IMUNOHISTOQUÍMICO E TOMOGRÁFICO EM COELHOS.}

Dissertação apresentada à Faculdade de Odontologia de Ribeirão Preto da Universidade de São Paulo, para a obtenção do título de Mestre em Cirurgia e Traumatologia Buco-Maxilo-Facial.

Data da defesa:

\section{Banca Examinadora}

Prof. Dr.

Instituição:

Julgamento:

Assinatura:

Prof. Dr.

Instituição:

Julgamento:

Assinatura:

Prof. Dr.

Instituição:

Julgamento: Assinatura: 


\section{DEDICO ESTE TRABALHO}

A Deus por ter me dado saúde, força e coragem pra superar todos os obstáculos e por ter me guiado até aqui.

Aos meus pais José Ossian Oliveira e Irene Alencar Oliveira que sempre me apoiaram, sofreram com minhas derrotas e vibraram com minhas vitórias, e principalmente torceram demais pra que eu pudesse alcançar meus objetivos, mesmo quando eles pareciam impossíveis. Agradeço imensamente toda segurança, amor e carinho que me proporcionaram, porque só assim pude seguir em frente.

Aos meus irmãos Renata Alencar Oliveira e Gustavo Alencar Oliveira, que além de torcerem demais por mim, tenho certeza que se fizeram presentes nas dificuldades encontradas em casa e deram o suporte necessário aos meus pais enquanto estava ausente.

Ao meu amor Clara Cavalcanti Cyrillo, que viajou inúmeras vezes até Ribeirão Preto para estar comigo, diminuindo um pouco da enorme distância que nos separava. Sempre me respeitou e me apoiou, e foi sem dúvida meu porto seguro nos meus momentos mais dificeis. Meu AMOR, obrigado! 


\section{AGRADECIMENTO ESPECIAL}

Ao meu orientador Prof. Dr. Luiz Antônio Salata, que além de me proporcionar um mundo inteiro de novos conhecimentos e me conceder várias oportunidades, sempre se mostrou disponivel e paciente.

Ao Prof. Dr. Valdemar Mallet da Rocha Barros que sempre esteve muito presente nas nossas disciplinas, ensinando, cobrando e incentivando cada um de nós, com muito vigor e principalmente compromisso com a responsabilidade de ser um PROFESSOR!

Ao Prof. Dr. Cássio Edvard Sverzut que além de se mostrar sempre disponível e atencioso, me deu muitos conselhos e me ajudou a trilhar os caminhos certos aqui em Ribeirão Preto.

Aos professores Prof. Dr. Adalberto Luiz Rosa, Prof. Dr. Alexandre Elias Trivellato e Prof. Dr. Paulo Tambasco de Oliveira pelos conhecimentos e experiência transmitidos. 


\section{AGRADECIMENTOS}

Aos meus amigos de mestrado, Aninha, Gustavão, Luciana, Marcelo, Michel, Rogerinho e Renam por todos os momentos de imensa alegria, satisfação e cumplicidade que compartilhamos aqui. Sinceramente a amizade de todos vocês é o maior tesouro que levo daqui de Ribeirão Preto, e mesmo cada um seguindo sua vida, espero reencontrá-los de tempos em tempos e poder sempre contar com vocês.

Agradeço às pessoas que foram fundamentais para a realização deste trabalho, Paulo Esteves Pinto Faria, Ariovaldo Theodoro, Antônio Sérgio Aparecido Mesca, Antônio Massaro e Vanir, pela enorme ajuda, disponibilidade e dedicação, e em especial aos meus amigos Gustavo Cavalcanti, Michel Campos Ribeiro, Marcelo Azenha e Renam Bueno por estarem sempre disponíveis para me ajudar nas cirurgias.

Aos meus amigos Marco Aurêlio Yamaji e William Marcati, que tive a grande sorte de conhecê-los e montar nossa república. Vocês são demais.

Aos meu amigos e conterrâneos, Cristiane Rocha, Rômulo Regis e Humberto Pinto, pela acolhida inicial e por todos os momentos que vocês se fizeram presentes na minha passagem aqui em Ribeirão. 
Às secretárias do Departamento de Cirurgia e Traumatologia Buco-Maxilo-Facial e Periodontia Tatiana Angeli Passos Fernandes e Aparecida Dulce de Oliveira Negretti, pela ajuda e paciência!

À FAPESP, Fundação de Amparo à Pesquisa do Estado de São Paulo, pelo suporte financeiro que possibilitou a execução deste projeto.

A FORP-USP por toda estrutura e acolhimento encontrada aqui, que me possibilitou adquirir novos conhecimentos. 


\section{RESUMO}

OLIVEIRA NETO, PJ. Estudo comparativo da fixação e integração de enxertos ósseos “onlay" com o uso de n-Butil-2-Cianocrilato ou parafuso de titânio. Estudo histológico, imunohistoquímico e tomográfico em coelhos. Ribeirão Preto, 2010. 55p. Dissertação [Mestrado] - Faculdade de Odontologia de Ribeirão Preto, Universidade de São Paulo.

Alguns trabalhos sobre a resposta do tecido ósseo ao Cianocrilato podem ser encontrados na literatura, embora nenhum deles avalie a resposta histológica e a fixação de enxertos ósseos onlay com o N-Butil-2-Cianocrilato (Indermil ${ }^{\mathrm{TM}}$ ). O objetivo do estudo proposto foi (1) analisar a manutenção do volume de enxertos ósseos onlay fixados à mandíbula de coelhos usando N-Butil-2-Cianocrilato (NB-Cn) ou parafuso de titânio, assim como avaliar (2) a remodelação e incorporação desses enxertos ao leito receptor e também (3) observar a diferença do nível de expressão da proteína tartarato-resistente ácido fosfatase (Trap) envolvida na absorção dos mesmos na presença do NB-Cn e do parafuso de titânio. Dezoito coelhos adultos foram envolvidos nesse estudo. Dois blocos ósseos provenientes da calvária dos coelhos foram transplantados para a mandíbula, em que de um lado do leito receptor o osso autógeno foi fixado com parafuso de osteossíntese (Grupo I - controle), e do outro lado com NB-Cn (Grupo II). Após o procedimento cirúrgico, os animais foram submetidos a exame tomográfico. O sacrifício dos animais ocorreu após $1(n=9)$ e $6(n=9)$ semanas do procedimento cirúrgico inicial, quando então os animais foram submetidos à nova tomografia. As imagens de tomografia foram usadas para estimativa da manutenção do volume dos enxertos. Cortes histológicos das áreas enxertadas foram preparados para se avaliar o reparo dos enxertos ósseos no sítio receptor e o nível de expressão da proteína Trap. Os resultados tomográficos mostraram melhor manutenção do volume dos enxertos fixados com NB-Cn $(p \leq 0,05)$ em comparação àqueles fixados com parafuso, em ambos os tempos experimentais. $\mathrm{Na}$ avaliação imunohistoquímica, observou-se que a marcação da proteína Trap no período de 6 semanas foi significativamente maior em comparação ao tempo de 1 semana, sem apresentar diferença significante entre os grupos. A análise histológica revelou que embora o NB-Cn tenha provocado a destruição do periósteo, a estabilidade promovida pela cola permitiu que a revascularização e incorporação do enxerto ocorresse de forma semelhante ao grupo controle. Esses resultados indicam que o NB-Cn se comportou de forma superior ao parafuso como material de osteossínte. No entanto, estudos adicionais são necessários para se investigar a toxicidade deste composto quando utilizado como meio de fixação óssea.

Palavras-chave: Cianocrilato, Enxerto Ósseo Onlay, Reparo Ósseo, Imunohistoquímica, Avaliação Tomográfica, Avaliação Histológica, Fixação de Enxertos Ósseos 


\begin{abstract}
OLIVEIRA NETO, PJ. Comparative study of the fixation and integration of "onlay" bone grafts with the use of n-Butyl-2-cyanoacrylate or titanium screw. Histological, immunohistochemical and $\mathbf{C T}$ in rabbits. Ribeirão Preto, 2010. 55p. Dissertação [Mestrado] - Faculdade de Odontologia de Ribeirão Preto, Universidade de São Paulo.
\end{abstract}

Some experimental studies on the bone tissue responses to cyanoacrylate can be found in the literature, although neither evaluating the histological response and the fixation of onlay bone grafts with Indermil ${ }^{\mathrm{TM}}$. The aim of the proposed study is (1) to analyze the bone grafts volume maintenance fixed to the mandible of rabbits using IndermilTM or titanium screw, as well as (2) assess the healing of onlay grafts to the recipient bed and (3) the differences of level expression of Trap protein involved in reabsortion of these bone grafts using Indermil ${ }^{\mathrm{TM}}$ or an osteosynthesis screw. Eighteen adult New Zealand White rabbits were submitted to calvaria onlay bone grafts on both sides of the mandible. On one side the onlay bone graft were fixated with Indermil ${ }^{\mathrm{TM}}$, and on the other side bone graft with an osteosynthesis screw. The wounds were then closed, and a computed tomography was realized immediately after this procedure. The animals were killed after $1(n=9)$ and 6 weeks $(n=9)$, then the animals were submitted to another computed tomography (CT). The CT images were used to estimate the bone grafts volume maintenance. Histological sections of the grafted areas were prepared to evaluate the healing of bone grafts in the receptor site and the expression level of Trap protein. The CT scan showed better volume maintenance of the bone grafts fixed with Indermil TM $(p \leq 0.05)$ compared to those fixed with screws, in both the experimental times. The immunohistochemical evaluation showed that the protein Trap expression in 6-week period was significantly higher compared to the 1-week period, without showing significant difference between the groups. Histological analysis revealed that although the Indermil $^{\mathrm{TM}}$ has caused the destruction of the periosteum, the stability provided by the glue allowed that the bone graft revascularization and incorporation has occurred in a similar manner to the control group. These results indicate that the Indermil $^{\mathrm{TM}}$ behaved than the screw as osteosynthesys material. However, further studies are needed to investigate the toxicity of this compound when used as a means of bone fixation.

Key Words: Cyanocrylate, Onlay Bone Graft, Healing Bone, Immunohistochemistry, Histologic evaluation, Tomographic evaluation, Bone Graft Fixation 


\section{Lista DE Figuras}

Figura 01 - Exposição da calota craniana de coelho (área doadora dos dois blocos ósseos). Notar aplicação tópica de PVP-I (polivinil-pirrolidona a 10\%) na área a ser operada.

Figura 02 - A. Blocos bicorticais de enxertos ósseos sendo obtidos da calota craniana de coelho com trefina de $08 \mathrm{~mm}$ de diâmetro. B. Enxertos obtidos mantidos em gaze umedecida

Figura 03 - A. Leito receptor mandibular padronizadamente perfurado com auxílio de guia cirúrgico. B. Guia cirúrgico utilizado para confecção de perfurações no leito receptor dos enxertos.

Figura 04 - Enxerto ósseo fixado na mandíbula do coelho com parafuso de titânio de 1,5 $\mathrm{mm}$ de diâmetro de um lado (A), e fixado com NB-Cn do outro (B)..

Figura 05 - Enxertos onlay na mandíbula, de um lado fixado com NB-Cn (A) e do outro com parafuso (B)

Figura 06 - A. Enxertos onlay na mandíbula, de um lado fixado com parafuso e do outro com NB-Cn. B. Fatia central dos enxertos delimitada com o uso da ferramenta "Surface" e suas medidas

Figura 07 - Deposição de osso novo imaturo (OI) em uma matriz extracelular de fibras colágenas frouxamente organizada unindo o enxerto (EO) ao leito ósseo receptor $(\mathrm{LR}) . \mathrm{It}=$ interface. $*=$ separação artefatual. $(100 \mathrm{x})$. Tricrômico de Mallory.

Figura 08 - Deposição de osso imaturo (OI) nas margens laterais do sítio enxertado logo abaixo do periósteo. $\mathrm{EO}=$ enxerto ósseo. $\mathrm{LR}=$ Leito receptor. ${ }^{*}=$ separação artefatual. (100x). Tricrômico de Mallory.

Figura 09 - Interface (It) enxerto ósseo (EO) / leito receptor (LR). Deposição de novo osso imaturo (OI), em uma matriz extracelular de fibras colágenas, localizado próximo a uma área de perfuração $(*)$ do leito receptor. Formação de novo osso imaturo ora parece vir do enxerto, ora parece vir do leito receptor. (100x). Tricrômico de Mallory.

Figura 10 - Nas margens do enxerto (EO) foi possível observar a presença do adesivo (NB-Cn) e o periósteo (Pt) sobrejacente respeitando sua presença. Notar a formação de osso imaturo abaixo do periósteo próximo ao leito receptor $(\mathrm{LR})$. It = interface $(25 \mathrm{x})$. Tricrômico de Mallory....

Figura 11 - Neoformação de osso imaturo (OI) no interior do enxerto. Reabsorção da cortical interna $(\mathrm{CI})$ do enxerto bem evidente $(*)$, chegando a comunicar seu conteúdo medular com a interface (It). CE = cortical externa. (100x). Tricrômico de Mallory.

Figura 12 - Processo de incorporação do enxerto (EO) ao leito receptor (LR) bem evidente, caracterizado por pontes de osso maduro (OM) e organizado com lamelas osteônicas unindo essas duas estruturas. It = interface. (100x). Tricrômico de Mallory

Figura 13 - Margem lateral do enxerto (EO) logo abaixo do periósteo (PT), onde se pode observar intensa formação de tecido ósseo maduro (*), assim como também na interface (It) entre o enxerto (EO) e o leito receptor (LR). (25x). Tricrômico de Mallory. 


\section{LISTA DE GRÁFICOS}

Gráfico 01 - Média da variação do volume dos enxertos (Volume no Sacrifício Volume Inicial) para cada grupo estudado no período de 1 e 6 semanas......... 55 


\section{LiSTA DE TABELAS}

Tabela 1 - Média, desvio padrão e comparação pelo teste t pareado entre a média do volume dos enxertos no tempo Inicial e no Sacrifício para cada grupo

Tabela 2 - Média da variação do volume dos enxertos ( $\Delta$ volume) em $\%$ entre a Fase de Sacrifício e a Inicial, em cada tempo experimental e para os dois grupos estudados

Tabela 3 - Intensidade de marcação para a proteína TRAP para ambos os tratamentos e nos dois tempos de sacrifício 


\section{Lista de AbreViaturas e Siglas}

EDTA - $\quad$ Ácido etilenodiamino tetra

PBS - $\quad$ Phosphate

Trap - $\quad$ Tartrate

Ti - $\quad$ Titânio

PLLA - $\quad$ PLGA

FORP-USP - Faculdade de Odontologia de Ribeirão Preto - Universidade de São Paulo

FAPESP - $\quad$ Fundação de Amparo à Pesquisa de Estado de São Paulo 


\section{LiSTA DE SÍMBOLOS}

TM - Trade Mark

p - $\quad$ Nível de significância

mg - $\quad$ Miligrama

g - $\quad$ Grama

Kg - Quilograma

ml - Mililitro

mm - Milímetro

$\mathbf{m m}^{2}$ - Milímetro quadrado

$\mathbf{m m}^{\mathbf{3}}$ - Milímetro cúbico

cm - $\quad$ Centímetro

pH - Potencial hidrogeniônico

KV - Quilovoltagem

mA - Miliamper 
Páginas

1. INTRODUÇÃO E JUSTIFICATIVA ......................................................................... 16

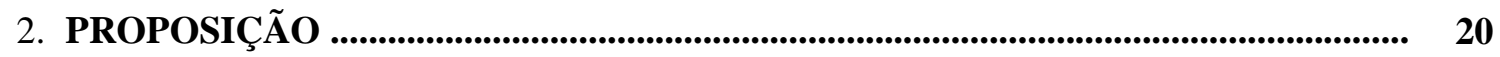

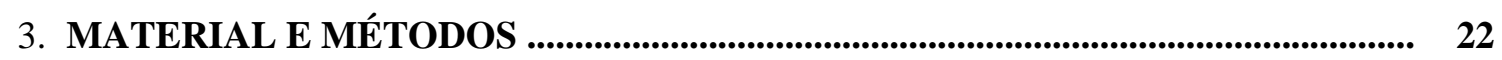

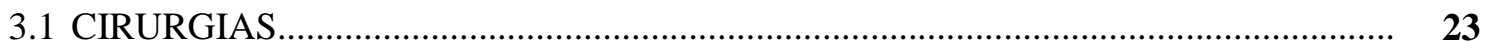

3.2 HISTOLOGIA E IMUNOHISTOQUÍMICA............................................................ 26

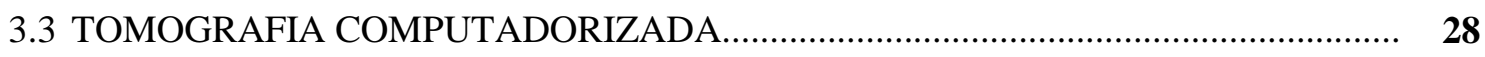

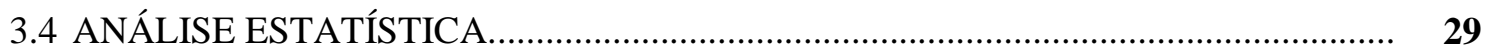

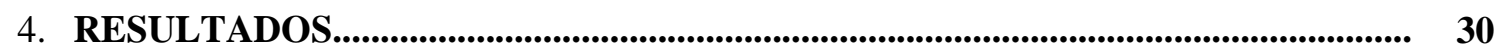

4.1 VOLUME DOS ENXERTOS ÓSSEOS................................................................. 31

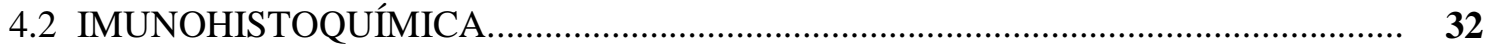

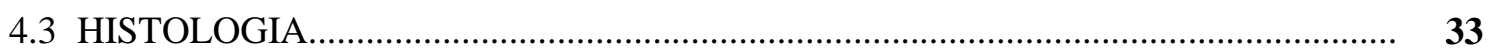

5. DISCUSSÃO

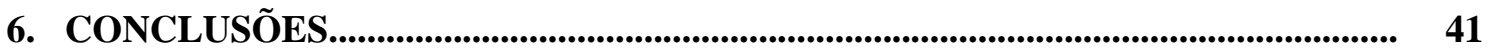

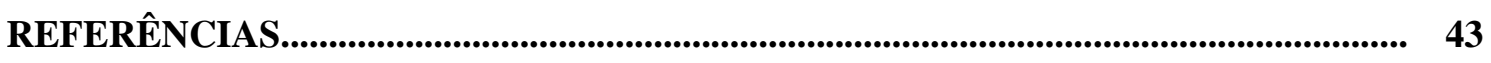

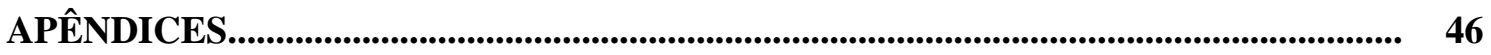


1.INTRODUÇÃO E JUSTIFICATIVA 


\section{INTRODUÇÃO E JUSTIFICATIVA}

A enxertia óssea onlay tem se tornado um procedimento rotineiro quando o aumento de volume ósseo é requerido para a reabilitação com implantes dentais (BLOCK; KENT, 1997;1998). O emprego de parafusos de Titânio (Ti) é o método de fixação de enxertos ósseos onlay mais utilizado atualmente. Entretanto, inúmeras desvantagens têm sido associadas a essa técnica, tais como: a produção de artefatos em exames de tomografia e ressonância magnética, corrosão no sítio implantado, reações alérgicas, infecção, afrouxamento dos parafusos, sensibilidade ao frio e reabsorção do osso alveolar causada por um fenômeno conhecido como "stress shielding". Nas áreas onde a pele ou mucosa sobrejacente é mais delgada, as placas e os parafusos podem se tornar visíveis e/ou palpáveis ou até mesmo tornarem-se expostos, trazendo algum desconforto para os pacientes e aumentando o risco de infecção e perda total do enxerto fixado. Além disso, enxertos pequenos e mais frágeis muitas vezes são inadequados para suportar a inserção de um parafuso para sua fixação. Finalmente, os sistemas de fixação são complexos, o que requer experiência profissional para sua utilização correta, e a alta tecnologia empregada para o desenvolvimento e fabricação desses sistemas de osteossíntese tornam o custo desses materiais relativamente elevado, trazendo outra desvantagem com a sua aplicação (AHN et al., 1997; AMARANTE et al., 1995; CHACON et al., 2004; GOSAIN et al., 1998; RAGHOEBAR et al., 2006; SHERMAK et al., 1998; 1998). Recentemente, placas e parafusos absorvíveis confeccionados de co-polímero biodegradável de ácido poliláctico e poliglicólico (PLLA-PLGA) têm sido desenvolvidos para evitar alguns desses problemas citados (AHN et al., 1997; CHACON et al., 2004; GOSAIN et al., 1998; RAGHOEBAR et al., 2006). Entretanto, a utilização de sistemas de fixação absorvível apresenta um custo ainda bastante elevado, e por outro lado, muitas vezes a conformação das placas e parafusos desse tipo de sistema torna seu manuseio e aplicação bastante dificultada e até mesmo impraticável em algumas situações clínicas. 
Todos esses inconvenientes têm estimulado o interesse por técnicas alternativas de fixação de enxertos. Estudos experimentais recentes em modelo animal têm analisado a resposta do tecido ósseo e a estabilidade em sítios de fraturas fixados com adesivo à base de cianoacrilato (AHN et al., 1997; AMARANTE et al., 1995; GOSAIN et al., 1998; SHERMAK et al., 1998; 1998), entretanto, não há trabalhos que avaliaram o processo de remodelação de enxertos onlay na presença desse material e nem a fixação desses enxertos promovida pelo adesivo e seus homólogos. O cianoacrilato foi descoberto por Ardis em 1949, tendo sido primeiramente aplicado em procedimentos cirúrgicos por Coover em 1959 (SHERMAK et al., 1998). Desde então tem sido utilizado nas mais diversas situações clínicas. Quando utilizada como meio de fixação óssea, a cola de cianocrilato tem algumas vantagens potenciais sobre o uso dos dispositivos de fixação metálicos e absorvíveis, tornando-se uma possível alternativa aos meios de osteossíntese convencional. Estas incluem o baixo custo, facilidade de uso, rapidez de aplicação, além de permitir a modificação da posição de fixação do enxerto durante o procedimento cirúrgico. Embora a polimerização deste composto ocorra dentro de um minuto, um fragmento ósseo pode ser facilmente reposicionado e fixado novamente dentro dos primeiros minutos sem qualquer detrimento à estrutura óssea (AHN et al., 1997; AMARANTE et al., 1995; SHERMAK et al., 1998). Outra vantagem é que como esse adesivo é aplicado na interface entre o enxerto e o leito ósseo receptor, não ocorre o aumento do perfil da área a ser reconstruída como acontece com a utilização de placas e parafusos (AMARANTE et al., 1995). Isto elimina os possíveis problemas de visibilidade e exposição desses materiais metálicos, evitando a necessidade de uma nova intervenção para a sua remoção. Além disso, os adesivos de cianoacrilato funcionam em ambiente úmido de forma que as superfícies a serem unidas não precisam estar totalmente secas. Acredita-se que os cianoacrilatos tenham efeitos bacteriostáticos e bactericidas, o que seria uma característica valiosa quando aplicados sobre tecidos que tenham 
sofrido uma injúria vascular ou em uma situação de ferimento contaminado. Há ainda o potencial de usar esse adesivo como veículo para administração de outras drogas como antibióticos e fatores de crescimento, os quais podem acelerar o reparo tecidual. Adicionalmente, em virtude de sua natureza não-metálica, os compostos de cianoacrilato não produzem artefatos de imagem em exames de tomografia ou ressonância magnética, e pelo fato de serem bioabsorvíveis eliminam a necessidade de procedimentos secundários para a remoção de dispositivos de fixação.

Existem diferentes formas deste composto e os membros de sua família incluem: o Metil-cianocrilato, Etil-cianocrilato, Octil-cianocrilato, o N-Butil-2-Cianocrilato (NB-Cn), dentre outros. O NB-Cn foi aprovado para uso clínico em 1996 e está se tornando um método bastante popular para fechamento de ferimentos cutâneos (INAL et al., 2006). Trata-se de um adesivo polimérico pertencente à nova geração de cianoacrilatos, os quais são compostos de cadeia longa, e que por isso são mais biocompatíveis do que aqueles usados inicialmente (PELISSIER et al., 2001). Assim como os outros cianoacrilatos, apresenta todas as propriedades e vantagens citadas anteriormente quando utilizado como material de fixação de fragmentos ósseos, o que o torna uma opção atrativa para essa finalidade.

Nosso grupo de pesquisa tem usado o NB-Cn para o reposicionamento e fixação da janela óssea obtida com acesso de Caldwel-Luck para cirurgia de levantamento de seio maxilar. Experiências advindas de casos clínicos têm indicado que o reparo desse enxerto ósseo reposicionado ao final da cirurgia não apresenta intercorrências na presença dessa cola. 
2. Proposição 


\section{Proposição}

Este estudo tem por objetivos: (1) analisar a variação do volume de enxertos ósseos obtidos da calvária e fixados à mandíbula de coelhos com adesivo à base cianoacrilato (NBCn) ou parafuso de Ti; (2) analisar histologicamente a dinâmica do processo de incorporação dos enxertos ao leito ósseo receptor e (3) avaliar o processo de remodelação dos enxertos através de método imunohistoquímico. 
3. Material e Métodos 


\section{Material e Métodos}

Para este estudo foram utilizados 18 coelhos adultos, machos, tipo New Zealand White, pesando 3,5 a 4,0 kg. Dois blocos ósseos provenientes da calota craniana dos coelhos foram transplantados para a mandíbula, em que de um lado do leito receptor o osso autógeno foi fixado com parafusos de titânio de $1,5 \mathrm{~mm}$ de diâmetro e $8,0 \mathrm{~mm}$ de comprimento de forma posicional (Grupo I - controle), e do outro lado a fixação do enxerto foi realizada com NB-Cn (Grupo II). Em ambos os grupos, os leitos receptores na mandíbula foram padronizadamente perfurados para dar condições de melhor revascularização e reparo dos enxertos.

Os animais foram provenientes do Biotério Central do Campus da USP - Ribeirão Preto. Após a seleção, os animais foram mantidos em gaiolas individuais no biotério I da FORP-USP nos períodos pré e pós-operatório, sob adequados cuidados veterinários, com livre acesso à água e suporte nutricional em padrão de laboratório durante todo o período de experimentação.

\subsection{CIRURGIAS}

Os procedimentos cirúrgicos foram realizados sempre sob anestesia geral, precedidos de sedação com acepromazina ${ }^{\circledR}(2,0 \mathrm{mg} / \mathrm{ml})$ na dose de $1,0 \mathrm{mg} / \mathrm{Kg}$ administrada por via subcutânea, 15 minutos antes da cirurgia. A seguir, por via intra-muscular profunda, foi realizada a anestesia geral com xilazina ${ }^{\circledR}(20 \mathrm{mg} / \mathrm{ml}$ - Calier Laboratories, Barcelona, Spain) na dose de 3,0mg/Kg misturada a quetamina $10 \%{ }^{\circledR}(50,0 \mathrm{mg} / \mathrm{ml}$ - União Química Farmacêutica Nacional S.A., Embuguaçú, São Paulo, Brasil) na dose de 60 mg/Kg. Após a anestesia, os animais receberam antibioticoterapia profilática com oxitetraciclina $(1,0 \mathrm{~g} / 10 \mathrm{ml})$ na dose de $0,2 \mathrm{ml} / \mathrm{Kg}$ e nos 3 dias subseqüentes por via intra-peritonial. Os animais receberam ainda analgésico buprenorfina $(0,3 \mathrm{mg} / \mathrm{ml})$ na dose de $0,02 \mathrm{mg} / \mathrm{kg}$ e anti-inflamatório 
(Profenid $^{\circledR}$ 100mg/2 ml - Distribuidora Farmácia Brasil LTDA , Jandira SP) na dose de 3,0 $\mathrm{mg} / \mathrm{Kg}$, ambos por via intra-muscular. Todas as cirurgias foram realizadas dentro de padrões assépticos e sempre pelo mesmo cirurgião. Todos os animais foram submetidos a cirurgias no crânio para obtenção dos enxertos autógenos, e cirurgias bilaterais na mandíbula, especificamente na região de corpo mandibular, logo abaixo da região de pré-molares e molares e posteriormente aos ápices dos incisivos, para fixação dos blocos ósseos obtidos. Em nenhum momento o padrão alimentar dos animais esteve prejudicado, uma vez que as incisões para a mandíbula foram realizadas por via extrabucal.

\section{OBTENÇÃO DOS ENXERTOS AUTÓGENOS}

Os procedimentos cirúrgicos de obtenção dos enxertos foram estes: com a sala cirúrgica a mais limpa possível (apropriada para uma cirurgia limpa de alto risco), o coelho sob efeito da anestesia geral foi submetido à tricotomia craniana. A área recebeu aplicação tópica de solução de iodo polivinil-pirrolidona a $10 \%$ e posteriormente, coberta com campos cirúrgicos, deixando exposto apenas a área a ser operada. A área a ser operada foi infiltrada com mepivacaína 2\% e noradrenalina 1:200.000. Uma incisão linear, diretamente sobre a pele, medindo $4,0 \mathrm{~cm}$, foi realizada ao longo da calota craniana ântero-posteriormente. A gálea e a fáscia foram incisadas e rebatidas, seguido de incisão periosteal para expor a cortical da calota craniana (Figura 1).

Dois blocos bicorticais de enxertos ósseos foram obtidos da calota craniana dos coelhos de forma padronizada, utilizando trefina de $08 \mathrm{~mm}$ de diâmetro, com auxílio de motor elétrico e peça de mão, para que todos os enxertos autógenos obtidos tivessem as mesmas medidas (Figura 2). As osteotomias foram realizadas sob irrigação abundante de solução fisiológica a $0,9 \%$ diretamente sobre a área ostectomizada. O fechamento da ferida foi realizado com vicryl 4.0 no periósteo, fáscia e gálea aponeurótica, e nylon 4.0 na pele, com 
pontos simples. Após a remoção dos dois blocos ósseos, os enxertos foram mantidos em gaze esterilizada umedecida em solução salina $0,9 \%$ até a preparação do leito ósseo receptor ter sido finalizada. Posteriormente, os dois blocos ósseos obtidos foram fixados cada um em um lado da mandíbula do coelho, obedecendo o tipo de fixação a ser empregado em cada enxerto.

\section{PREPARO DO LEITO RECEPTOR E FIXAÇÃO DO ENXERTO}

O acesso cirúrgico na mandíbula foi por via submandibular, sendo que uma incisão de aproximadamente $1,5 \mathrm{~cm}$ foi realizada bilateralmente em direção à base da mandíbula. Estas incisões deveriam transpor pele, fáscia, músculo e periósteo, até chegar à região de implantação dos enxertos localizada posteriormente à saída do nervo mentual. Todos os procedimentos foram realizados sob rígidos critérios cirúrgicos de controle de cadeia asséptica.

Em ambos os lados mandibulares dos coelhos foram confeccionadas perfurações monocorticais dos leitos receptores, visando facilitar a comunicação entre a camada trabecular do leito receptor e a cortical do enxerto. Tais perfurações foram realizadas sob irrigação abundante com soro fisiológico e a distribuição das mesmas foi padronizada utilizando guia confeccionado em aço cirúrgico (medindo 7x7mm), com nove perfurações de 1,0 $\mathrm{mm}$ de diâmetro, distribuídas de maneira eqüidistante (Figura 3).

De um lado da mandíbula (Grupo I - controle), um bloco de osso autógeno obtido foi fixado com parafusos de titânio de $1,5 \mathrm{~mm}$ de diâmetro, por técnica posicional, e do outro lado (Grupo II) o segundo bloco ósseo foi fixado com NB-Cn (Figura 4) aplicado somente nas bordas do enxerto. Nesse momento foi realizada uma perfuração monocortical na superfície do enxerto voltada para os tecidos moles, com o objetivo de se inserir material obturador endodôntico (Guta-percha) para permitir o registro da posição inicial dos enxertos do grupo II 
quando da tomada tomográfica. O fechamento da ferida foi realizado com vicryl 4-0 no periósteo e plano muscular, e nylon 4-0 na pele, com pontos simples.

\section{SACRIFÍCIO DOS ANIMAIS}

Decorrido o período experimental de 1 e 6 semanas, os animais (9 coelhos para cada tempo experimental) foram sacrificados por meio de sobredose de Tiopental 1,0 $\mathrm{g}(2 \mathrm{ml})$ administrado por via endovenosa. Nestes tempos experimentais, os animais foram submetidos a novo exame tomográfico da mandíbula. Após as tomografias, os segmentos da mandíbula contendo os grupos experimentais foram removidos, dissecados e posteriormente reduzidos em blocos individuais para serem processados e incluídos em parafina para a confecção das lâminas (Figura 5).

\subsection{HISTOLOGIA E IMUNOHISTOQUÍMICA}

Blocos ósseos contendo a área enxertada na mandíbula dos coelhos foram removidos, fixados em Formalina tamponada 10\% com pH 7,4 (por no mínimo 24 horas). Após a fixação, as peças foram descalcificadas com EDTA 4\% trocado duas vezes por semana. Após descalcificação, os blocos ósseos foram lavados em água corrente por mais ou menos 08 horas, seguido de desidratação por meio de uma sequiência de álcoois com concentração crescente (50 a 100\% de 2 em 2 horas). Após desidratação, foi realizada a diafanização com a colocação das peças em Xilol (três soluções de 2 em 2 horas) até ficarem transparentes. A seguir, foi então feita a impregnação em parafina, em estufa $60^{\circ} \mathrm{C}$ em três banhos de 3 horas. A próxima etapa foi a inclusão das peças em formas com parafina, a qual endureceu com as peças totalmente embebidas.

Os blocos de parafina contendo as peças foram cortados em micrótomo de maneira padronizada ( $0,5 \mathrm{~mm}$ de espessura), sendo 20 cortes por enxerto (02 a 03 cortes por lâmina), 
sendo 03 lâminas para avaliação histológica, 04 lâminas destinadas a imunohistoquímica (sendo 03 lâminas para avaliação de 03 proteínas + 01 lâmina para controle negativo) e 03 lâminas que ficarão de reserva.

A análise histológica teve como objetivo avaliar a incorporação dos enxertos ao leito receptor mandibular, mais especificamente na interface entre o osso enxertado e a mandíbula, fazendo uma análise comparativa entre os dois grupos (grupo I e II) das diferentes características teciduais encontradas nessa interface.

\section{PROCESSAMENTO PARA IMUNOHISTOQUÍMICA}

O processo de absorção óssea foi reconhecido utilizando-se marcação para a enzima tartarato-resistente ácido fosfatase (Trap). A peroxidase endógena foi bloqueada pela incubação das lâminas com peróxido de hidrogênio 3\% em PBS por 40 minutos, seguida pela recuperação de epítopos por aquecimento em tampão citrato de sódio $0,05 \mathrm{M}, \mathrm{pH} 6,0$, a $55^{\circ} \mathrm{C}$ por 20 minutos. Por último, a biotina endógena, foi bloqueada pela incubação em solução com avidina (leite Molico 3\%) por 20 minutos. O anticorpo primário foi incubado por 18 horas a $4^{\circ} \mathrm{C}$. O controle negativo da imunomarcação foi feito com a incubação em PBS-BSA em vez de anticorpo primário. O controle positivo foi realizado em uma área distinta dos sítios experimentais previstos no projeto, ou seja, na região lingual da mandíbula. O passo seguinte foi a incubação com o anticorpo secundário biotinilado anti-imunoglobulina de cabra (705-065-I47; Jackson Immuno research Laboratories, West Grove, PA, USA) por 1h, à temperatura ambiente. Ato contínuo, as lâminas foram incubadas com o complexo avidinabiotina-peroxidase (Duet Kit, Dako), à temperatura ambiente por 45 minutos. Por último, para revelar a imunomarcação, foi usado como cromógeno a DAB (3,3'-diaminobenzidina tetrahidrocloridrato) e a hematoxilina de Harris como contra marcação. 
Foram realizadas análises microscópicas qualitativas e semi-quantitativas dos materiais processados utilizando aumentos de 100x e 200x. Para esta análise foi utilizada uma classificação subjetiva de quatro níveis de concentração de imunomarcações $(0,1,2$ e 3$)$. A estimativa de imunomarcação foi realizada próximo às margens do enxerto, na sua superfície e na interface, para tentar obter uma quantificação padronizada de imunomarcação, tendo sido realizada por dois observadores.

\subsection{TOMOGRAFIA COMPUTADORIZADA}

Os exames tomográficos foram realizados imediatamente após as cirurgias de implantação dos enxertos e também após os sacrifícios. Os cortes tomográficos foram analisados no software Dicom Works v 1.3.5b para análise do volume dos enxertos de forma bilateral.

Os exames foram realizados em equipamento de tomografia computadorizada helicoidal modelo Emotion ${ }^{\mathrm{TM}}$ (Siemens, Elrlangen, Germany), instalado no Hospital das Clínicas da Faculdade de Medicina de Ribeirão Preto - USP. Foram realizados aquisições volumétricas helicoidais no plano axial à mandíbula do animal, com $110 \mathrm{KV}$ e $60 \mathrm{MAS}$, com "rotation time" de 1 segundo, incremento contínuo da mesa de $1 \mathrm{~mm}$ e espessura de corte de 1,0 mm. A reconstrução será de 1,0 mm de espessura, com filtro de alta resolução espacial (“Sharp”), matriz 512x512 e campo de visão (FOV) de $150 \mathrm{~mm}$, resultando num tamanho de voxel de $0,5 \times 0,3 \times 0,3 \mathrm{~mm}$.

As imagens foram geradas em padrão DICOM e transferidas para uma "Workstation PC" para visualização e realização de medidas do volume do enxerto em $\mathrm{mm}^{3}$. 


\section{CÁLCULO DO VOLUME DO ENXERTO}

Utilizando o software Dicom Works v.1.3.5b, a imagem de cada fatia do enxerto foi delimitada por meio da ferramenta "Surface", nos cortes mais centrais do enxerto, utilizando o parafuso de um lado e a marcação de gutapercha no outro como referência central do enxerto. Ao final da delimitação de cada fatia do enxerto, é obtido um valor correspondente à área daquela imagem em $\mathrm{mm}^{2}$, e assim sucessivamente até que todos os cortes desejados tenham sido analisados. Ao término da demarcação da superfície do enxerto para cada um dos seus cortes mais centrais, todos os valores foram somados e o valor do volume total do enxerto calculado pelo programa em $\mathrm{mm}^{3}$ (Figura 6).

\subsection{ANÁLISE ESTATÍSTICA}

Os dados foram descritos em tabelas e gráficos com os parâmetros de média e desvio padrão. Os dados tomográficos passaram pelo critério de normalidade avaliado pelo teste de Shapiro-Wilk.

O teste $\mathrm{T}$ pareado foi utilizado para comparar o volume dos enxertos entre as fases inicial e de sacrifício nos diferentes tempos experimentais em cada grupo de tratamento.

Para a comparação da variação de volume sofrida pelos enxertos entre os tempos experimentais e os dois tipos de tratamento empregados na fixação dos mesmos, foi utilizado Análise de Variância a dois critérios modelo misto.

Em relação aos dados da marcação imunohistoquímica foram utilizados testes nãoparamétricos na análise. Para comparação entre os lados foi utilizado o teste de Wilcoxon e para a comparação entre os tempos foi utilizado o teste de Mann-Whitney.

Em todos os testes estatísticos foi adotado nível de significância de 5\% (p<0,05).

Todos os cálculos foram executados no programa Statistica for Windows versão 5.1 (Statsoft Inc., Tulsa, USA) 


\section{RESULTADOS}

Todos os animais suportaram bem os procedimentos cirúrgicos e o pós-operatório ocorreu sem maiores complicações.

\section{Volume dos Enxertos Ósseos}

Após a coleta dos dados tomográficos e exploração dos mesmos por meio da aplicação de teste estatístico específico, foi possível construir uma tabela composta de média e desvio padrão comparando a média do volume dos enxertos entre a fase inicial e a fase de sacrifício para os dois tempos experimentais e em cada grupo de tratamento avaliado. Tendo como base esses resultados, observamos nos dois grupos de tratamento estudados que a média do volume dos enxertos não se alterou de forma significativa entre a fase inicial e a fase de sacrifício, em ambos os tempos experimentais (Tabela 1).

Em relação à média da variação de volume dos enxertos no decorrer dos tempos experimentais e para cada tipo de tratamento empregado, foi observado que não houve diferença estatística na variação do volume entre os tempos de tratamento (1 e 6 semanas), assim como também não houve interação entre os fatores de variação tempo e tipo de tratamento. No entanto, observou-se diferença estatisticamente significante da variação do volume entre os dois tratamentos (parafuso x NB-Cn) $(\mathrm{p}<0,05)$, em que o grupo II (NB-Cn) se comportou de maneira superior na manutenção do volume dos enxertos em comparação ao grupo I (parafuso), em ambos os tempos experimentais, com uma média total de variação positiva do volume dos enxertos $=+3,81 \%$, contra uma média de $-2,15 \%$ do grupo I. Os dados foram montados em uma tabela composta de média e desvio padrão dessa variação de volume (Tabela 2) e representados em um gráfico (Gráfico 1). 


\section{Imunohistoquímica}

Após a coleta dos dados da imunomarcação para a proteína Trap e exploração dos mesmos por meio da aplicação de teste estatístico específico, foi possível construir uma tabela composta de mediana, média e desvio padrão comparando as intensidades de marcação no momento de sacrifício para os dois tempos experimentais e em cada grupo de tratamento avaliado (Tabela 3). A Trap é uma enzima que está presente em grandes quantidades na borda corrugada dos osteoclastos, sendo liberada no espaço absortivo entre essa borda e a superfície do osso subjacente durante a absorção óssea.

De acordo com os resultados, observamos que embora a mediana de intensidade de marcação para a proteína Trap tenha sido maior nos enxertos fixados com parafuso, esta não apresentou diferença estatística em comparação ao grupo fixado com NB-Cn, em ambos os tempos experimentais ( 1 semana: $p=0,109 ; 6$ semanas: $p=0,285$ ). No entanto, os resultados da análise mostraram que houve diferença estatisticamente significante entre os dois tempos de sacrifício, tanto para o grupo NB-Cn $(p=0,007)$ como para o grupo parafuso $(p=0,03)$, em que a intensidade de marcação no período de 6 semanas foi significativamente maior em comparação ao tempo de 1 semana. As células positivas à proteína Trap estavam predominantemente localizadas na interface e na superfície do enxerto. 


\section{Histologia}

Grupo I - Parafuso de Titânio

No período experimental de sete dias, os enxertos ósseos pareciam estar quase completamente preservados com raros pontos de absorção. Na interface enxerto/leito receptor pôde-se observar clara deposição de osso novo imaturo em uma matriz extracelular de fibras colágenas frouxamente organizada unindo o enxerto ao leito ósseo receptor, assim como também nas margens laterais do sítio enxertado logo abaixo do periósteo (Figura 7 e 8 ).

Após seis semanas, foi possível observar intenso processo de remodelação do enxerto e neoformação óssea a partir do endósteo, havendo reabsorção de porções da cortical interna assim como também sua união com a cortical externa por meio de trabéculas de osso maduro. $\mathrm{Na}$ interface enxerto/leito receptor foi encontrado tecido ósseo maduro com organização lamelar, assim como também nas margens laterais do sítio enxertado abaixo do periósteo, evidenciando o processo de incorporação do enxerto.

\section{Grupo II - NB-Cn}

No período experimental de sete dias, os enxertos encontravam-se completamente preservados. $\mathrm{Na}$ interface enxerto/leito receptor, foi observada em algumas situações uma nítida deposição de novo osso imaturo, em uma matriz extracelular de fibras colágenas, geralmente localizado próximo a uma área de perfuração do osso residente. Esta formação de novo osso imaturo ora parecia vir do enxerto, ora parecia vir do leito receptor (Figura 9). Já em outros casos, observamos na interface apenas um tecido conjuntivo fibroso que por vezes se apresentava denso e outras vezes frouxamente organizado. Nas margens do enxerto foi possível observar a presença do adesivo e o periósteo sobrejacente respeitando sua presença (Figura 10). No entanto, na maioria dos casos o periósteo sobre o enxerto encontrava-se destruído. 
Após seis semanas, os enxertos encontravam-se vitais, com a arquitetura preservada e neoformação óssea ocorrendo no interior dos mesmos. A cortical interna, entretanto, apresentava um processo de reabsorção intenso chegando a comunicar o conteúdo medular dos enxertos com a interface (Figura 11). Nesse período experimental, o processo de incorporação do enxerto ao leito receptor era bem evidente, caracterizado por pontes de osso maduro e organizado com lamelas osteônicas unindo essas duas estruturas. Fibras colágenas frouxamente organizadas completam o quadro na interface (Figura 12). Da mesma forma, nas margens laterais do enxerto e logo abaixo do periósteo, pôde-se observar intensa formação de tecido ósseo maduro, de onde na verdade parece ter iniciado o processo de incorporação do enxerto ao osso mandibular receptor (Figura 13). O periósteo encontrava-se regenerado, diferentemente do que foi observado no período de uma semana, em que o periósteo encontrava-se destruído na maioria das vezes. 
5. DISCUSSÃO 


\section{DiscuSSÃo}

O enxerto de osso autógeno é amplamente utilizado na reconstrução de rebordos alveolares atróficos e atualmente acredita-se que ele deva ser fixado de forma estável ao leito ósseo receptor quando aplicado para aumento em altura e espessura. Diversos trabalhos demonstraram que a fixação interna estável com parafusos diminui a absorção de enxertos ósseos onlay quando comparada com a fixação promovida por meio de fios de aço ou mesmo na ausência de fixação (PHILIPS; RAHN, 1998; LIN et al., 1990; LA TRENTA et al., 1989). Philips e Rahn (1998) demonstraram em ovelhas que o volume dos enxertos foi mais bem preservado quando foram fixados com parafusos, comparados com os que foram fixados com fio de aço ou sem fixação. O mesmo resultado foi encontrado por La Trenta et al. (1989) em estudo em cães. Baseado nessas evidências, o uso de placas e parafusos de titânio é o método mais utilizado atualmente na fixação de enxertos ósseos, por promover uma maior estabilidade dos mesmos. Entretanto, o uso de dispositivos metálicos para a fixação dos enxertos traz algumas desvantagens: a produção de artefatos em exames de imagem; alto custo dos materiais empregados; risco de exposição do parafuso que pode levar à infecção, além de outras citadas anteriormente.

Os adesivos à base de cianocrilato se apresentam como uma possível alternativa aos métodos de osteossíntese com materiais metálicos para a fixação de blocos ósseos, ao promover uma fixação menos rígida sem prejudicar a incorporação e manutenção volumétrica dos enxertos. Estudos experimentais têm mostrado resultados semelhantes entre segmentos ósseos fixados com placas e parafusos de titânio e aqueles fixados com cola de cianocrilato. Shermak et al. (1998) avaliaram o reparo de segmentos de osso da calvária de coelho fixados com microplacas ou adesivo à base de cianocrilato. Após 8 semanas de fixação, os autores observaram que a estabilidade dos segmentos promovida pelo adesivo resultou em um reparo ósseo comparável ao dos segmentos fixados com placa e parafuso. Amarante et al. (1995), em 
um estudo realizado em mini-porcos, mostraram que o n-butil-2-cianocrilato foi tão efetivo quanto as placas e parafusos na fixação de fragmentos osteotomizados criados no esqueleto facial. Os autores observaram a ocorrência de união óssea entre os fragmentos e o sítio receptor para ambos os tipos de fixação e encontraram que a resistência biomecânica da união óssea também foi semelhante. Entretanto, nenhum trabalho avaliou o uso de NB-Cn na fixação de enxertos ósseos onlay quanto aos aspectos histológicos, imunohistoquímicos e tomográficos da incorporação e manutenção do volume dos enxertos, em comparação ao uso de parafusos metálicos.

No presente estudo, os enxertos do grupo parafuso apresentaram variação negativa de volume em ambos os tempos experimentais ( 1 e 6 semanas) comparados ao momento de instalação dos enxertos. Contrariamente, o grupo adesivo apresentou variação de volume positiva nos mesmos períodos. Saska et al. (2009) em estudo histométrico em calvária de coelhos, também encontraram uma maior preservação do volume dos enxertos fixados com o etil-cianocrilato comparados com parafusos de titânio. Os blocos fixados com parafuso sofreram maior perda de volume ósseo e os autores atribuíram esse efeito à pressão interna exercida pela compressão do parafuso sobre o enxerto. Entretanto, no grupo etil-cianocrilato, os enxertos não haviam sido completamente incorporados ao leito ósseo receptor mesmo após 120 dias de experimentação. Diferentemente do nosso estudo, o adesivo foi aplicado em toda a extensão da interface entre o enxerto e o sítio receptor, bem como o leito ósseo não foi perfurado. Além disso, a presença do adesivo mesmo após 120 dias no estudo de Saska e colaboradores pode ter interferido na revascularização e incorporação dos enxertos, já que é conhecido que a degradação do etil-cianocrilato ocorre somente após 12 meses (TORIUMI et al., 1990), o que pode explicar em parte o resultado obtido pelos autores. No nosso estudo, o adesivo foi aplicado somente nas bordas do enxerto, e não detectamos a presença do NB-Cn 
após 42 dias de experimento, o que sugere que a formulação do NB-Cn seria mais adequada para procedimentos de osteossíntese com adesivos.

A análise histológica revelou que em ambos os grupos o processo de incorporação do enxerto ao leito receptor já era observado no período de uma semana e que esse processo encontrava-se praticamente terminado no período de seis semanas, com a presença de tecido ósseo lamelar na interface óssea. A deposição de tecido ósseo em ambos os grupos teve seu início a partir das margens do enxerto como resultado de um processo de "reação periosteal" e da maior proximidade entre as bordas do enxerto e o sítio receptor. Este quadro histológico tem sido descrito por outros autores em trabalhos semelhantes (ALBERIUS et al., 1998; GORDH et al., 1997; FARIA et al., 2008; PEDROSA et al., 2009) e ratifica a importância desses dois fatores na incorporação de blocos ósseos onlay. A revascularização dos enxertos ocorreu à custa da reabsorção da sua cortical interna em ambos os grupos, comunicando a interface com seu conteúdo medular e contribuindo para a remodelação e neoformação óssea acentuada no período de 6 semanas. No entanto, essa remodelação encontrava-se bem mais intensa nos enxertos do grupo controle ao final desse período. Freqüentemente, o grupo NBCn esteve relacionado com degeneração do periósteo no período de uma semana, sugerindo uma reação à presença do adesivo. Esse fato pode explicar em parte o atraso na remodelação dos blocos ósseos fixados com adesivo.

A origem da reabsorção de enxertos ósseos onlay ainda não é completamente conhecida. Estudos tomográficos e imunohistoquímicos recentes realizados pelo nosso grupo mostraram diferenças significantes em favor da calvária quando comparados à crista ilíaca em termos de manutenção de volume dos enxertos (FARIA et al., 2008; PEDROSA et al., 2009), confirmando a importância da microarquitetura dos enxertos no remodelamento e manutenção de volume ao longo do tempo (OZAKI; BUCHMAN, 1998). Em uma dessas pesquisas, Pedrosa et al. (2009) publicaram um estudo no qual dados tomográficos, histológicos e de 
imunohistoquímica da incorporação de enxertos de calvária foram comparados em relação à presença e ausência de perfurações sobre o leito receptor. Com base nos resultados, os autores concluíram que o volume ósseo de enxertos de calvária é melhor mantido quando o leito receptor é perfurado, provavelmente em virtude de uma melhor revascularização do enxerto e osteogênese. Portanto, pressupõe-se que não apenas a microarquitetura do enxerto, como também um preparo adequado do leito receptor, são fundamentais para a sua manutenção de volume. Na presente investigação, utilizou-se então a mesma metodologia empregada no estudo anterior. Todos os enxertos foram obtidos da mesma região do crânio, foram recortados em tamanho padronizado e adaptados à forma do leito receptor perfurado, variando-se apenas o método de fixação dos mesmos ao leito receptor. É razoável que essa diferença em relação ao método de fixação possa ter contribuído para a discrepância de remodelamento e perda de volume no grupo em que se utilizou o parafuso, já que as outras variáveis, microarquitetura e preparo do leito receptor, foram controladas. Assim, a perfuração do próprio enxerto ósseo e do leito receptor para instalação do parafuso pode ter criado uma via precoce de revascularização do enxerto, o que não ocorreu no grupo do adesivo. Esse processo agudo de revascularização do enxerto pode ter levado a um remodelamento ósseo mais intenso que resultou em perda do volume especialmente nos tempos mais remotos. A constatação de que o escore de marcações da proteína TRAP tendeu ser maior no grupo parafuso no período de 1 semana corrobora essa afirmação. Neste experimento, a cortical óssea interna do enxerto no grupo NB-Cn foi antes submetida à reabsorção para que o enxerto fosse revascularizado, o que pode explicar um remodelamento ósseo menos intenso nesse grupo. Entretanto, estudos mais específicos são necessários para estabelecer a influência do parafuso de fixação no remodelamento dos enxertos onlay.

A fixação promovida pelo adesivo, embora menos rígida em comparação ao parafuso, forneceu estabilidade suficiente ao conjunto enxerto/leito receptor para que ocorresse a 
neoformação óssea na interface e nas margens do bloco ósseo. Uma desvantagem apresentada é que o adesivo de cianocrilato provocou a destruição do periósteo no período de 1 semana, embora isso não tenha prejudicado a revascularização e incorporação do enxerto. Diversos estudos clínicos têm mostrado o uso de cianocrilato em cirurgia bucal (INAL et al., 2006; GHOREISHIAN et al., 2009; CHOI et al., 2006; GIRAY et al., 1997), assim como também sua utilização em procedimentos como embolização vascular, síntese de ferimentos em pele, agente hemostático, dentre outros (CARNEIRO et al., 2009; VAN DEN ENDE et al., 2004; SINHA et al., 2001). No entanto, em nenhum desses estudos qualquer efeito tóxico foi reportado com o uso dos compostos à base de cianocrilato. O NB-Cn é um composto de cadeia longa, pertencente à nova geração de cianocrilatos, sendo mais biocompatível do que aqueles utilizados inicialmente (PELISSIER et al., 2001). No entanto, Pelissier et al. ( 2001), em um estudo utilizando o NB-Cn para fechamento de ferimentos cutâneos no dorso de ratos, observaram edema e uma moderada reação inflamatória aguda quando da análise histológica dos ferimentos. Dessa forma, estudos adicionais são necessários para se investigar melhor a biocompatibilidade do NB-Cn quando utilizado como meio de fixação óssea. 


\section{Conclusões}




\section{Conclusões}

$\checkmark$ O NB-Cn promoveu reações locais especialmente relacionadas ao periósteo sem causar prejuízos à incorporação dos enxertos;

$\checkmark$ A estabilidade promovida pelo NB-Cn ocorreu de forma semelhante ao grupo controle;

$\checkmark$ Comparado aos enxertos fixados com parafuso, o NB-Cn apresentou melhores resultados quanto à manutenção do volume, provavelmente como resultado de revascularização e remodelação ósseas precoces ocorridas no grupo controle. 
REFERÊNCIAS BIBLIOGRÁFICAS 


\section{REFERÊNCIAS BIBLIOGRÁFICAS}

1. Ahn, D.K.; Sims, C.D.; Randolph, M.A.; O’Connor, D.; Butler, P.E.M.; Amarante, M.T.J.; Yaremchuk, M.J. Craniofacial Skeletal Fixation Using Biodegradable Plates and Cyanocrilate Glue. Plastic and Reconstructive Surgery, v. 99, p. 1509 - 1515. 1997.

2. Alberius, P.; Gordh, M. Osteopontin and Bone Sialoprotein Distribution at the Bone Graft Recipient Site. Archives Otolaryngology Head Neck Surgery, v. 124, p.1382-1386. 1998.

3. Amarante, M.T.J.; Constantinescu, M.A.; O’Connor, D.; Yaremchuk, M.J. Cyanocrylate Fixation of the Craniofacial Skeleton: An Experimental Study. Plastic and Reconstructive Surgery, v. 95, p. 639 - 646. 1997.

4. Block, M.S.; Kent, J.N.; Kallukaran, F.U.; Thuntby, K.; Weinberg, R. Bone Maintenance 5 to 10 Years After Sinus Grafting. Journal of Oral and Maxillofacial Surgery, v. 56, p. 706-714. 1998.

5. Block, M.S.; Kent, J.N. Sinus Augmentation for Dental Implants:The Use of Autogenous Bone. Journal of Oral and Maxillofacial Surgery, v. 55, p. 1281 - 1286. 1997.

6. Carneiro, S.C.A.S.; Batista, L.L.; Vasconcelos, B.C.E.; Maranhão, C.A.; Panazzolo, G.; Queiroz, I.V.; Medeiros, R. Massive Oral Hemorrhage Due To Mandibular Arteriovenous Malformation Treated With Percutaneous Approach - A Case Report. Journal of Oral and Maxillofacial Surgery, v. 67, p. 2525-2528. 2009.

7. Chacon, G.E.; Ellis, J.P.; Kalmar, J.R.; McGlumphy, E.A. Usin Resorbable Screws for Fixation of Cortical Onlay Bone Grafts: An in Vivo Study in Rabbits. Journal of Oral and Maxillofacial Surgery, v. 62, p. 1396 - 1402. 2004.

8. Choi, B.; Kim, K.; Huh, J.; Lee, S.; Zhu, S.; Jung, J.; Li, J. Cyanoacrylate adhesive for closing sinus membrane perforations during sinus lifts. Journal of Cranio-Maxillofacial Surgery, v. 34, p. 505-509. 2006.

9. Faria, P.E.P.; Okamoto, R. ; Bonilha-Neto, R.M. ; Xavier, S.P. ; Santos, A.C. ; Salata, L.A. Immunohistochemical, Tomographic and Histological Study on Onlay Iliac Grafts Remodeling. Clinical Oral Implants Research, v. 19,p. 393 - 401. 2008.

10. Ghoreishian, M.; Gheisari, R.; Fayazi, M. Tissue adhesive and suturing for closure of the surgical wound after removal of impacted mandibular third molars: A comparative study. Oral Surgery Oral Medicine Oral Pathology Oral Radiology Oral Endodontics, v.108, p.e14-e16. 2009.

11. Giray, C.B.; Atasever, A.; Durgun, B.; Araz, K. Clinical and electron microscope comparison of silk sutures and n-butyl-2-cyanoacrylate in human mucosa. Australian Dental Journal, v.42, p.255-258. 1997.

12. Gordh, M.; Alberius, P.; Lindberg, L.; Johnell, O. Bone graft incorporation after cortical perforations of the host bed. Otolaryngology Head and Neck Surgery, v. 117, p.664-70. 1997.

13. Gosain, A.K.; Sogan, L.; Corrao, M.A.; Pintar, F.A. Biomechanical Evaluation of Titanium, Biodegradable Plate and Screw, and Cyanocrilate Glue Fixation Systems in Craniofacial Surgery. Plastic and Reconstructive Surgery, v. 101, p. 582 - 591. 1998. 
14. Inal, S.; Yilmaz, N.; Nisbet, C.; Güvenç, T.; Samsun, T. Biochemical and Histopatological Findings of N-Butyl-2-Cyanocrylate in Oral Surgery - an experimental study. Oral Surgery Oral Medicine Oral Pathology Oral Radiology Oral Endodontics, v. 102, p. e14 - e17. 2006.

15. La Trenta, G.S.; McCarthy, J.G.; Breitbart, A.S.; May, M.; Sissons, H.A. The Role of Rigid Skeletal Fixation in Bone-Graft Augmentation of the Craniofacial Skeleton. Plastic and Reconstructive Surgery, v. 84, p. 578-588. 1989.

16. Lin, K.Y.; Bartlett, S.P.; Yaremchuck, M.J. ; Fallon, M.; Grossman, R.F.; Whitaker, L.A. The Effect of Rigid Fixation on the Survival of Onlay Bone Grafts: An Experimental Study. Plastic and Reconstructive Surgery, v. 86, p. 449-456. 1990.

17. Ozaki, W.; Buchman, S.R. Volume maintenance of onlay bone grafts in the craniofacial skeleton: micro-architeture versus embryologic origin. Plastic and Reconstructive Surgery, v. 102, p. 291-299.1998.

18. Pedrosa, W.F.Jr.; Okamoto, R.; Faria, P.E.P.; Arnez, M.F.M.; Xavier, S.P.; Salata, L.A. Immunohistochemical, tomographic and histological study on onlay bone grafts remodeling. Part II: calvarial bone. Clinical Oral Implants Research, v. 20, p.12541264. 2009.

19. Pelissier, P.; Casoli, V.; Le Bail, B.; Martin, D.; Baudet, J. Internal Use of n-Butyl 2Cyanoacrylate (Indermil) for Wound Closure: An Experimental Study. Plastic and Reconstructive Surgery, v. 108, p. 1661 - 1666. 2001.

20. Philips, J.H.; Rahn, B.A. Fixation effects on Membranous and Endocondral Onlay BoneGraft resorption. Plastic and Reconstructive Surgery, v. 82, p. 872-877. 1998.

21. Raghoebar, G.M.; Liem, R.S.B.; Bos, R.R.M.; Van der Wal, J.E.; Vissink, A. Resorbable screws for fixation of autologous bone grafts. Clinical Oral Implants Research, v.17, p. 288-293. 2006.

22. Saska, S.; Hochuli-Vieira, E.; Minarelli-Gaspar, A.M.; Gabrielli, M.F.R.; Capela, M.V.; Gabrielli, M.A.C. Fixation of autogenous bone grafts with ethylcyanoacrylate glue or titanium screws in the calvaria of rabbits. International Journal of Oral and Maxillofacial Surgery, v. 38, p.180-186. 2009.

23. Shermak, M.A.; Wong, L. ; Inoue, N. ; Crain, B.J. ; Im, M.J. ; Chao, E.Y.S. ; Manson, P. Fixation of the Craniofacial Skeleton witn Butyl-2-Cyanocrylate and Its Effects on Histotoxicity and Healing. Plastic and Reconstructive Surgery, v. 102, p. 309 - 317. 1998.

24. Shermak, M.A.; Wong, L.; Inoue, N.; Chao, E.Y.S.; Manson, P.N. Butyl-2-Cyanocrylate Fixation of Mandibular Osteotomies. Plastic and Reconstructive Surgery, v. 102, p. 319324. 1998.

25. Sinha, S.; Naik, M.; Wright, V.; Timmons, J.; Campbell, A.C. A Single Blind, Prospective, Randomized Trial Comparing N-Butyl 2-Cyanoacrylate Tissue Adhesive (Indermil) And Sutures For Skin Closure In Hand Surgery. Journal of Hand Surgery, v. 26B, p.264-265. 2001.

26. Toriumi, D.M.; Raslan, W.F.; Friedman, M.; Tardy, E. Histotoxicity of cyanoacrylate tissue adhesives. A comparative study. Archives Otolaryngology Head Neck Surgery, v. 116, p.546-550. 1990.

27. Van den Ende, E.D.; Vriens, P.W.H.E.; Allema, J.H.; Breslau, P.J. Adhesive Bonds or Percutaneous Absorbable Suture for Closure of Surgical Wounds in Children. Results of a Prospective Randomized Trial. Journal of Pediatric Surgery, v. 39, p.1249-1251. 2004. 
APÊNDICES

ב




\section{APÊNDICE A - FIGURAS}

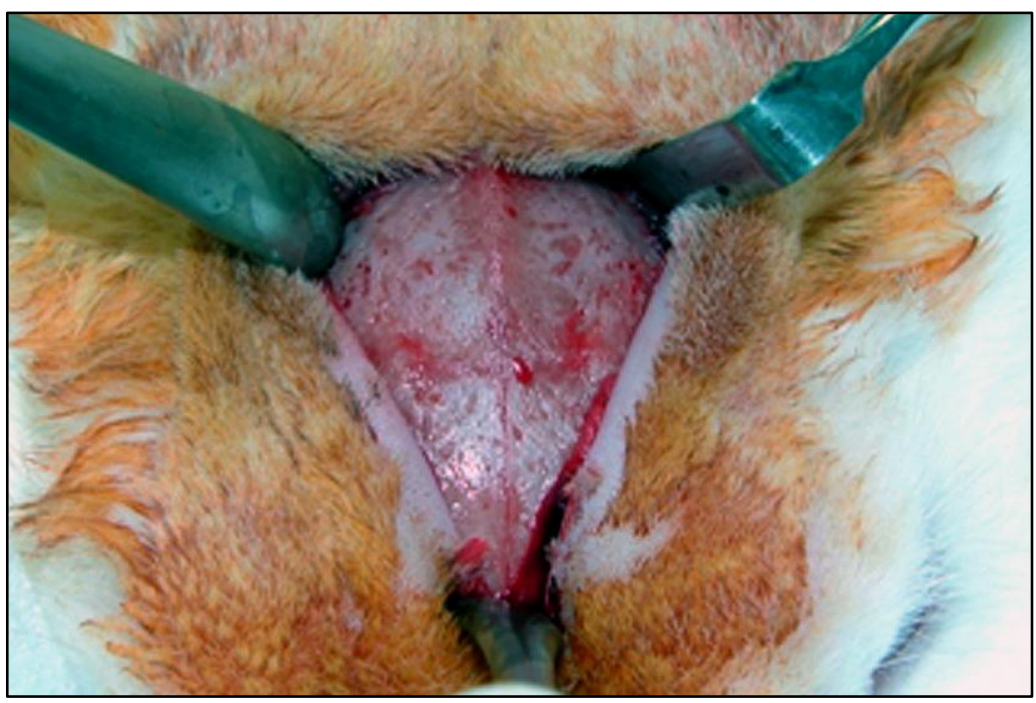

Figura 1 - Exposição da calota craniana de coelho (área doadora dos dois blocos ósseos). Notar aplicação tópica de PVP-I (polivinil-pirrolidona a 10\%) na área a ser operada.

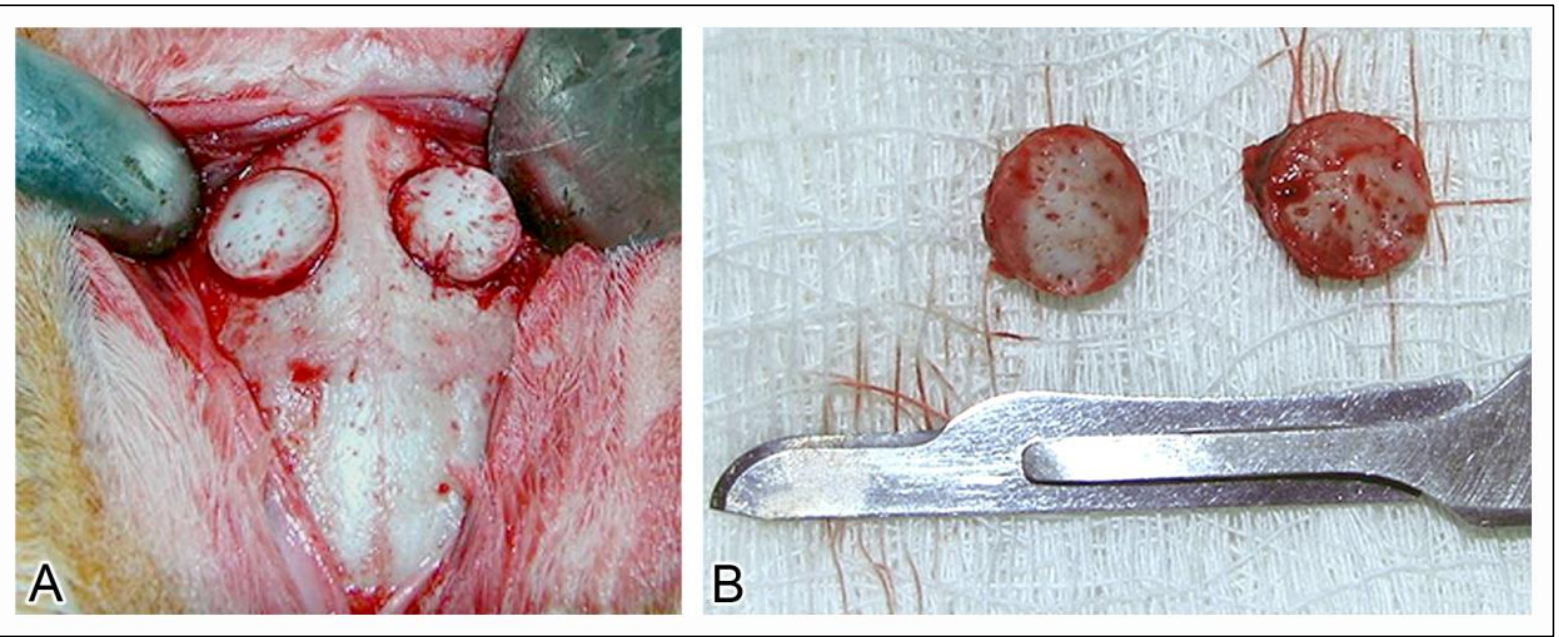

Figura 2 - A. Blocos bicorticais de enxertos ósseos sendo obtidos da calota craniana de coelho com trefina de $08 \mathrm{~mm}$ de diâmetro. B. Enxertos obtidos mantidos em gaze umedecida. 


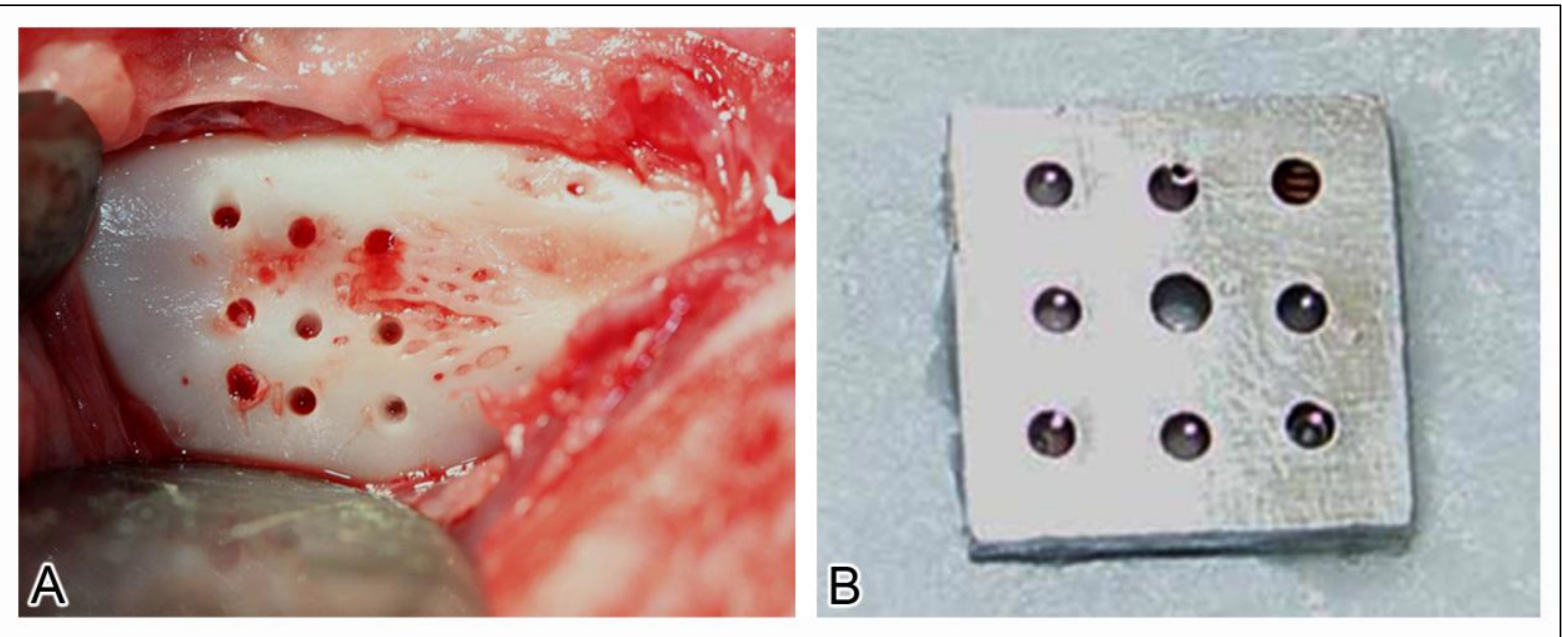

Figura 3 - A. Leito receptor mandibular padronizadamente perfurado com auxílio de guia cirúrgico. B. Guia cirúrgico utilizado para confecção de perfurações no leito receptor dos enxertos.

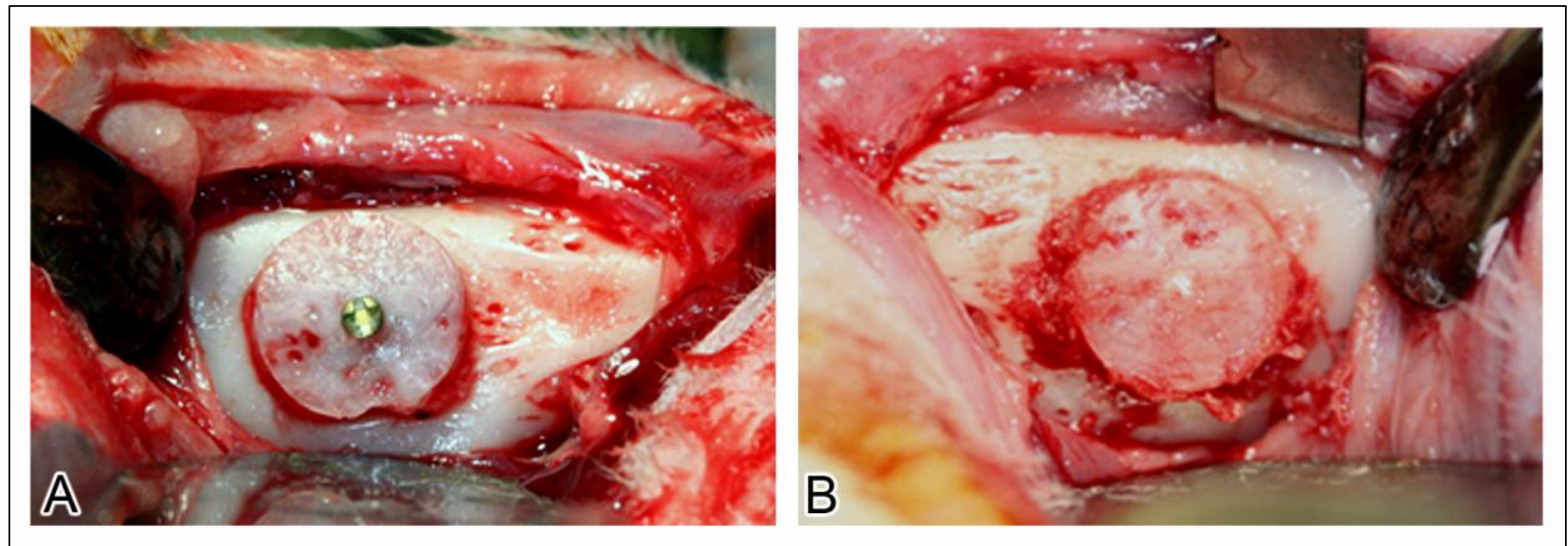

Figura 4 - Enxerto ósseo fixado na mandíbula do coelho com parafuso de titânio de 1,5 mm de diâmetro de um lado (A), e fixado com NB-Cn do outro (B). 


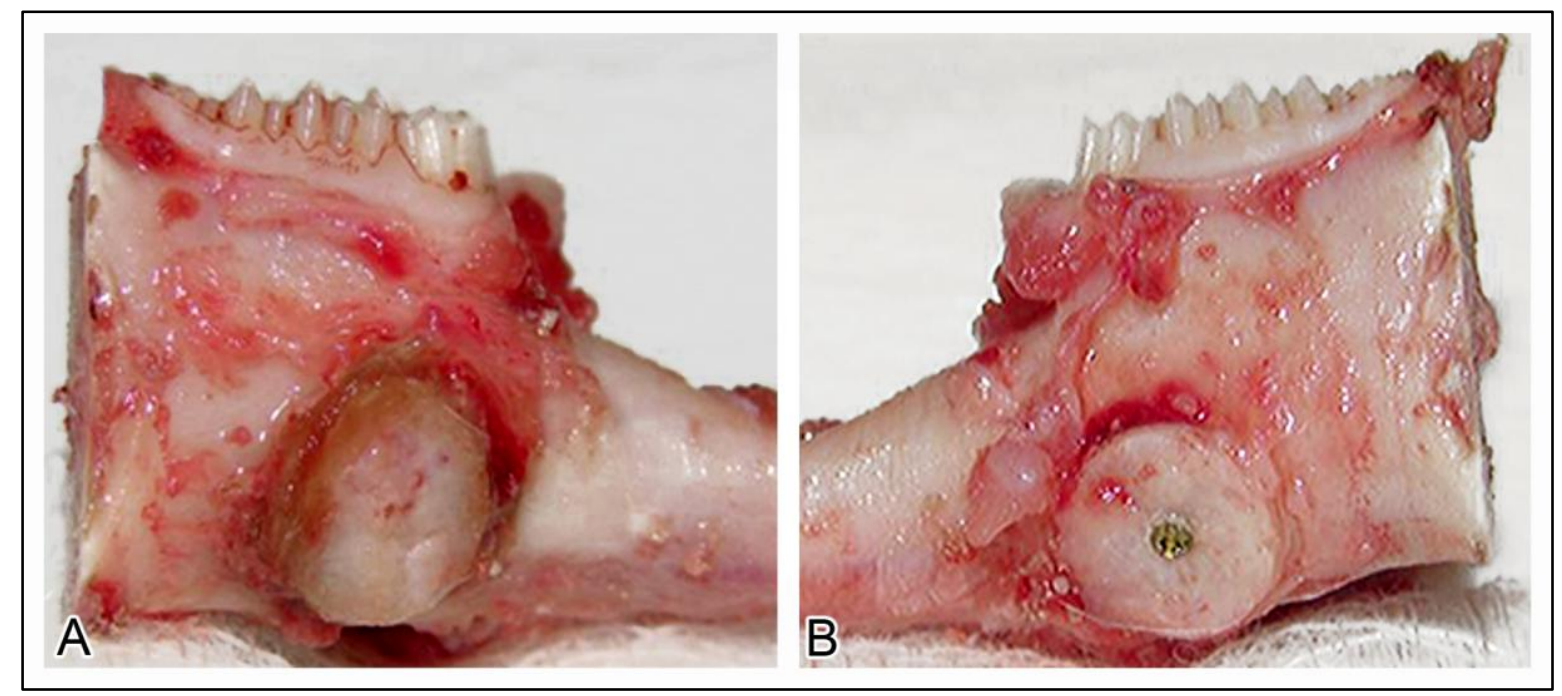

Figura 5 - Enxertos onlay na mandíbula, de um lado fixado com NB-Cn (A) e do outro com parafuso (B).

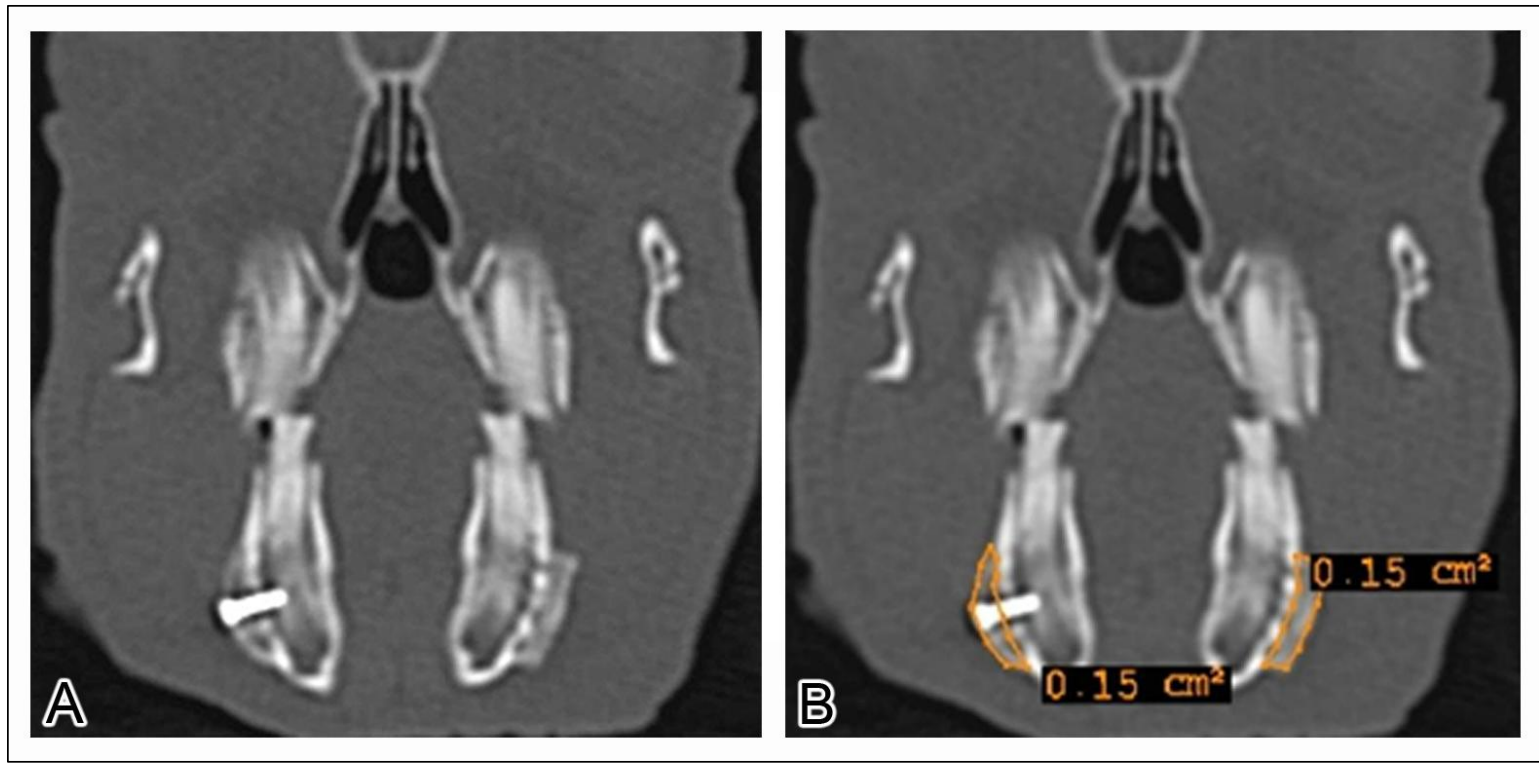

Figura 6 - A. Enxertos onlay na mandíbula, de um lado fixado com parafuso e do outro com NB-Cn. B. Fatia central dos enxertos delimitada com o uso da ferramenta "Surface" e suas medidas. 


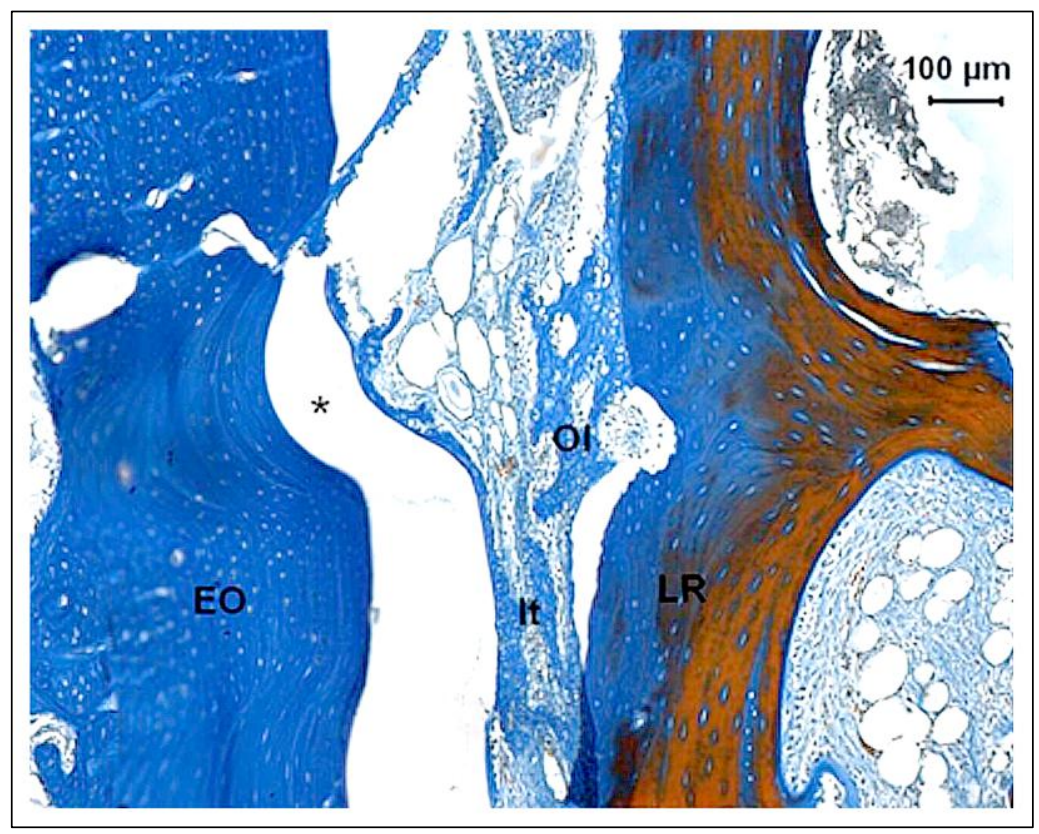

Figura 7 - Deposição de osso novo imaturo (OI) em uma matriz extracelular de fibras colágenas frouxamente organizada unindo o enxerto $(\mathrm{EO})$ ao leito ósseo receptor $(\mathrm{LR})$. It $=$ interface. ${ }^{*}=$ separação artefatual. (100x). Tricrômico de Mallory.

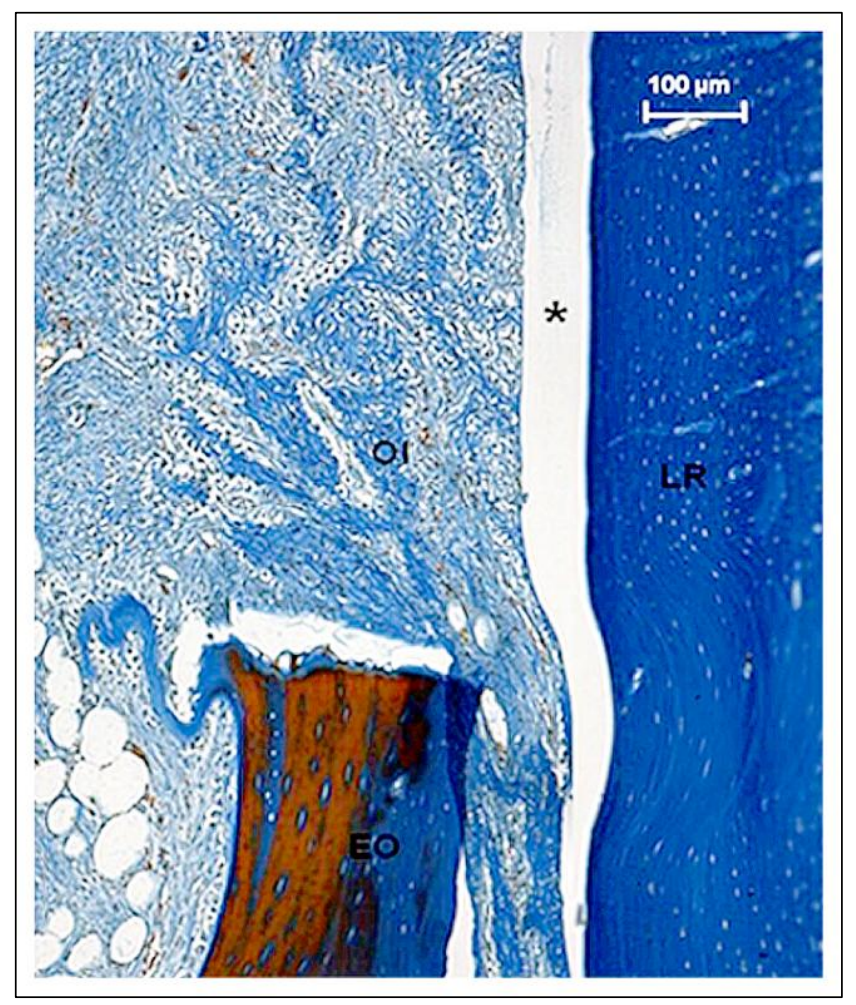

Figura 8 - Deposição de osso imaturo (OI) nas margens laterais do sítio enxertado logo abaixo do periósteo. $\mathrm{EO}=$ enxerto ósseo. $\mathrm{LR}=$ Leito receptor. ${ }^{*}=$ separação artefatual. $(100 \mathrm{x})$. Tricrômico de Mallory. 


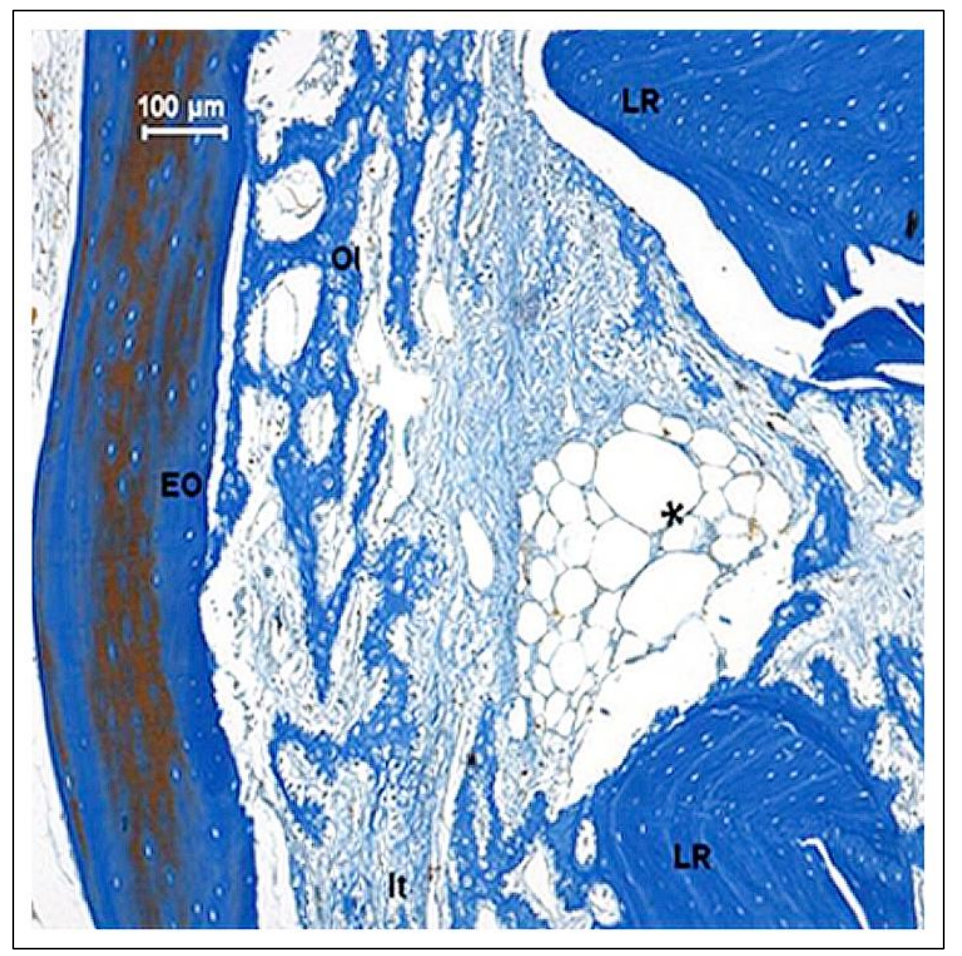

Figura 9 - Interface (It) enxerto ósseo (EO) / leito receptor (LR). Deposição de novo osso imaturo $(\mathrm{OI})$, em uma matriz extracelular de fibras colágenas, localizado próximo a uma área de perfuração $\left(^{*}\right)$ do leito receptor. Formação de novo osso imaturo ora parece vir do enxerto, ora parece vir do leito receptor. (100x). Tricrômico de Mallory.

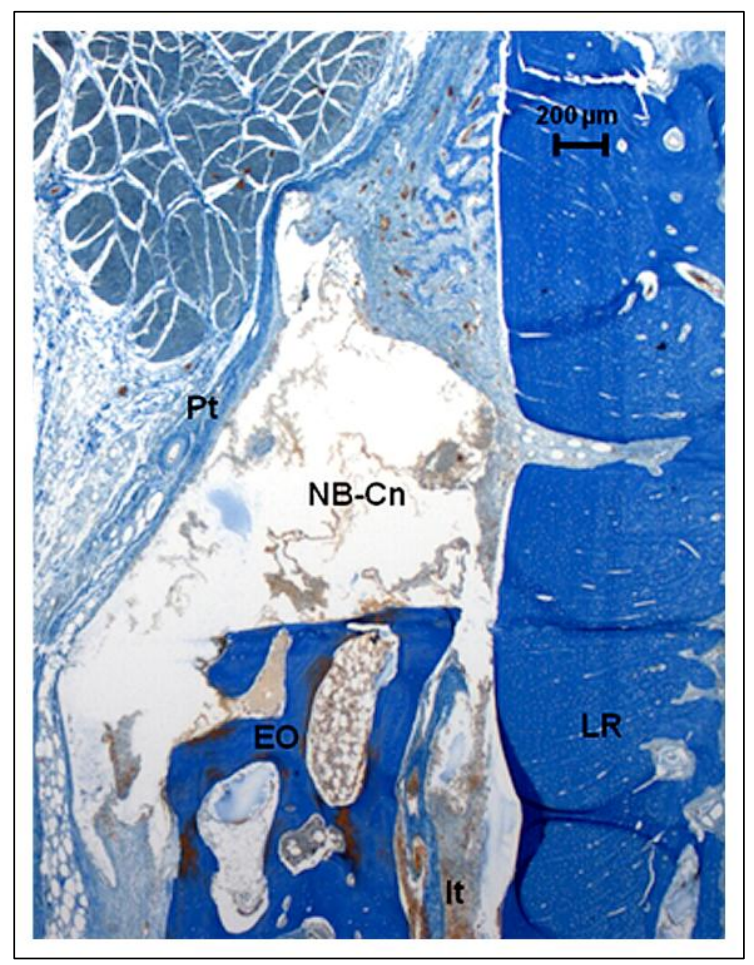

Figura 10 - Nas margens do enxerto (EO) foi possível observar a presença do adesivo (NB-Cn) e o periósteo $(\mathrm{Pt})$ sobrejacente respeitando sua presença. Notar a formação de osso imaturo abaixo do periósteo próximo ao leito receptor (LR). It = interface (25x). Tricrômico de Mallory. 


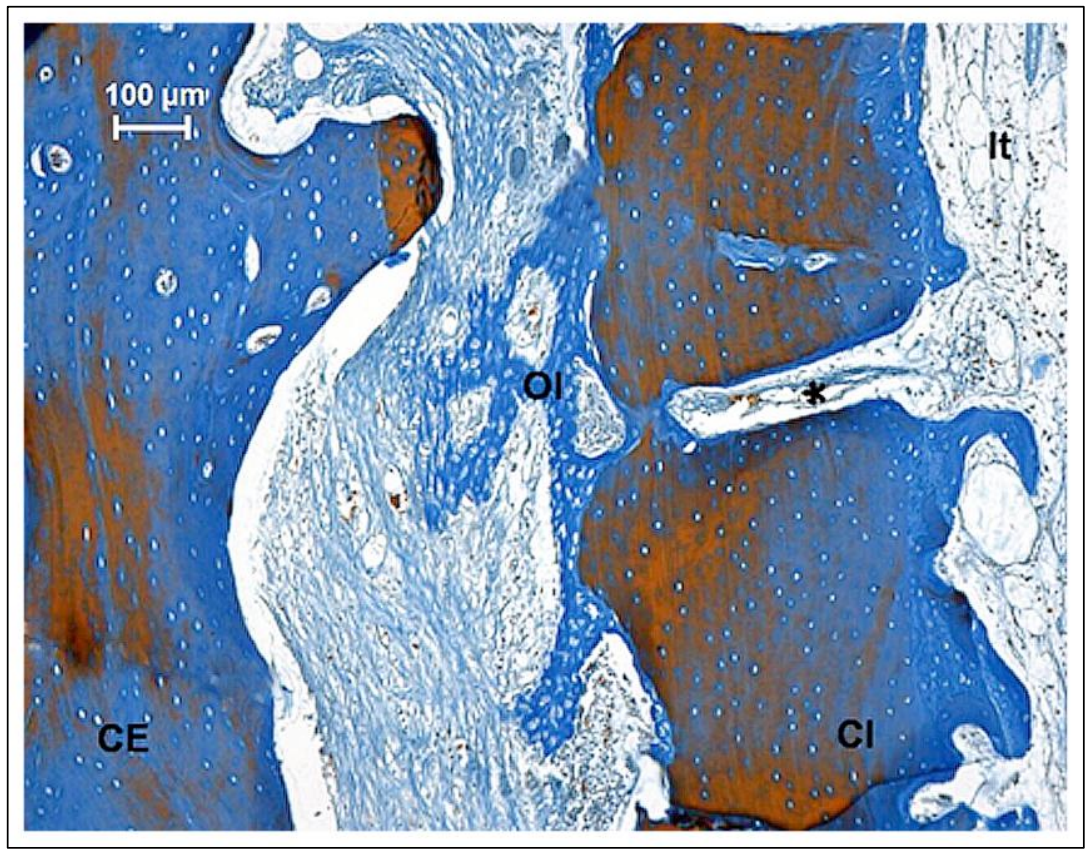

Figura 11 - Neoformação de osso imaturo (OI) no interior do enxerto. Reabsorção da cortical interna (CI) do enxerto bem evidente $(*)$, chegando a comunicar seu conteúdo medular com a interface (It). $\mathrm{CE}=$ cortical externa. (100x). Tricrômico de Mallory.

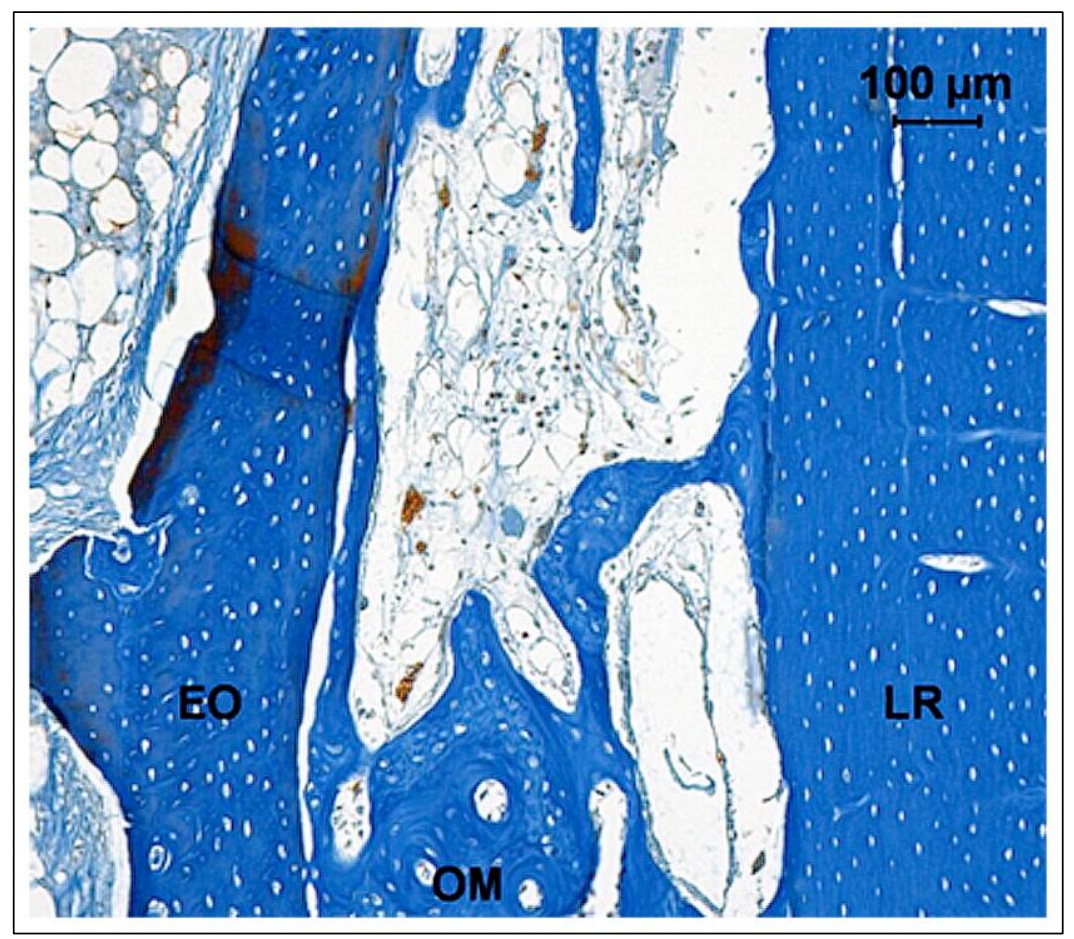

Figura 12 - Processo de incorporação do enxerto (EO) ao leito receptor (LR) bem evidente, caracterizado por pontes de osso maduro $(\mathrm{OM})$ e organizado com lamelas osteônicas unindo essas duas estruturas. It $=$ interface. $(100 x)$. Tricrômico de Mallory. 


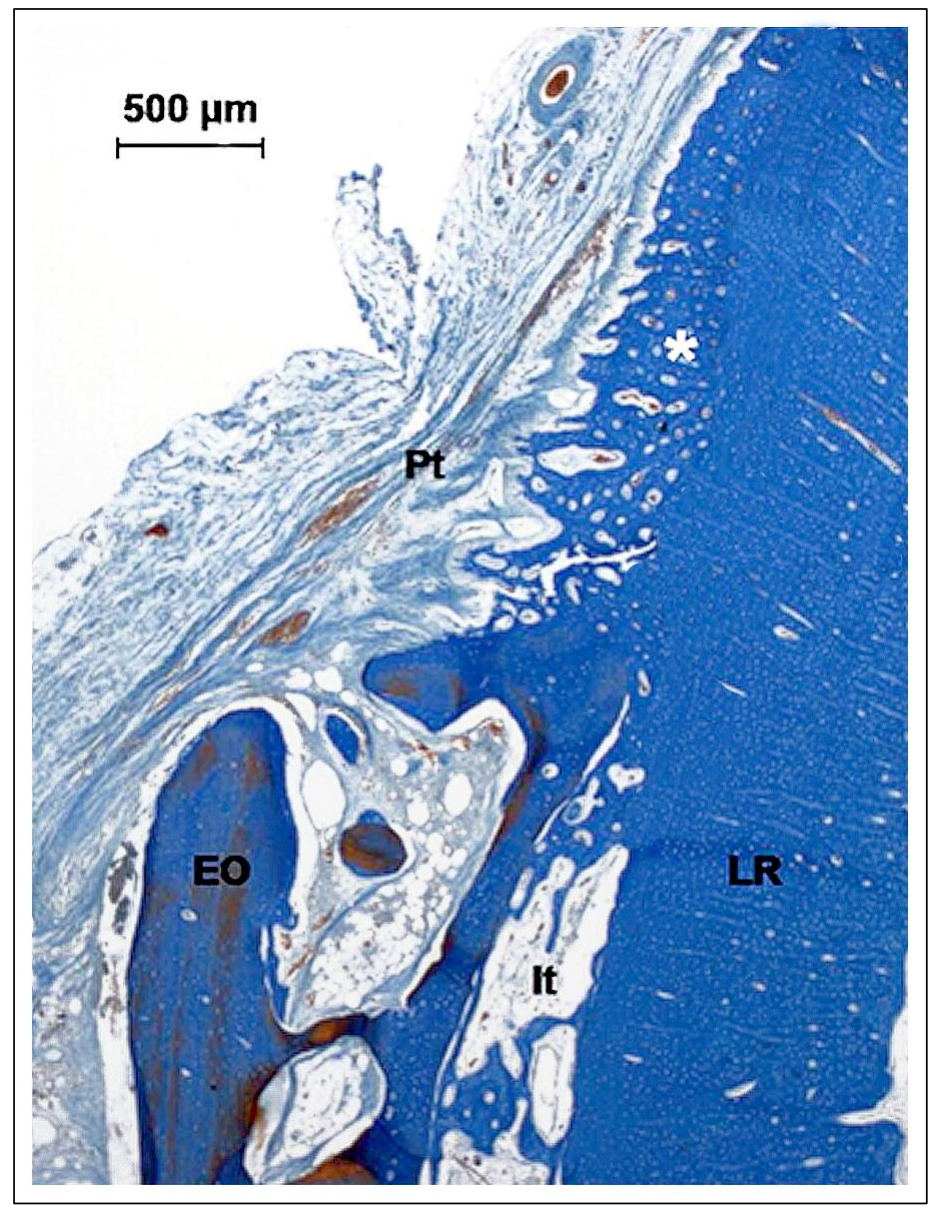

Figura 13 - Margem lateral do enxerto (EO) logo abaixo do periósteo (PT), onde se pode observar intensa formação de tecido ósseo maduro $(*)$, assim como também na interface (It) entre o enxerto (EO) e o leito receptor (LR). (25x). Tricrômico de Mallory. 


\section{APÊNDICE B - Gráficos e Tabelas}

Tabela 1 - Média, desvio padrão e comparação pelo teste t pareado entre a média do volume dos enxertos no tempo Inicial e no Sacrifício para cada grupo.

\begin{tabular}{ccccccc}
\hline \multirow{2}{*}{ Tempo } & Grupo & \multicolumn{2}{c}{ Inicial } & \multicolumn{2}{c}{ Sacrifício } & \multirow{2}{*}{ p } \\
\cline { 3 - 6 } & & $\begin{array}{l}\text { Média } \\
\left(\mathbf{m m}^{\mathbf{3}}\right)\end{array}$ & $\mathbf{d p ~ ( \pm )}$ & $\begin{array}{c}\text { Média } \\
\left(\mathbf{m m}^{3}\right)\end{array}$ & $\mathbf{d p ~ ( \pm )}$ & \\
\hline $\begin{array}{c}\text { 1 } \\
\text { semana }\end{array}$ & Parafuso (I) & 113,20 & 11,48 & 112,76 & 11,44 & $0,863 \mathrm{~ns}$ \\
& NB-Cn(II) & 122,63 & 17,34 & 126,14 & 17,45 & $0,527 \mathrm{~ns}$ \\
\multirow{2}{*}{6 semanas } & Parafuso (I) & 123,85 & 22,13 & 119,19 & 28,31 & $0,153 \mathrm{~ns}$ \\
& NB-Cn (II) & 114,65 & 18,00 & 120,21 & 25,28 & $0,330 \mathrm{~ns}$ \\
\hline
\end{tabular}

ns - diferença estatisticamente não significante.

Tabela 2 - Média da Variação do Volume dos enxertos ( $\Delta$ volume) em \% entre a Fase de Sacrifício e a Inicial, em cada tempo experimental e para os dois grupos estudados.

\begin{tabular}{ccccc}
\hline & \multicolumn{2}{c}{ NB-Cn } & \multicolumn{2}{c}{ Parafuso } \\
\cline { 2 - 5 } Tempo & Média $(\%)$ & dp $( \pm)$ & Média $(\%)$ & dp $( \pm)$ \\
\hline \multirow{2}{*}{1 semana } & $3,70^{\mathrm{a}}$ & 13,47 & $-0,21^{\mathrm{b}}$ & 6,60 \\
6 s semanas & $4,67^{\mathrm{a}}$ & 13,33 & $-4,68^{\mathrm{b}}$ & 8,52 \\
\hline
\end{tabular}

Letras Iguais $=$ sem diferença estatística 


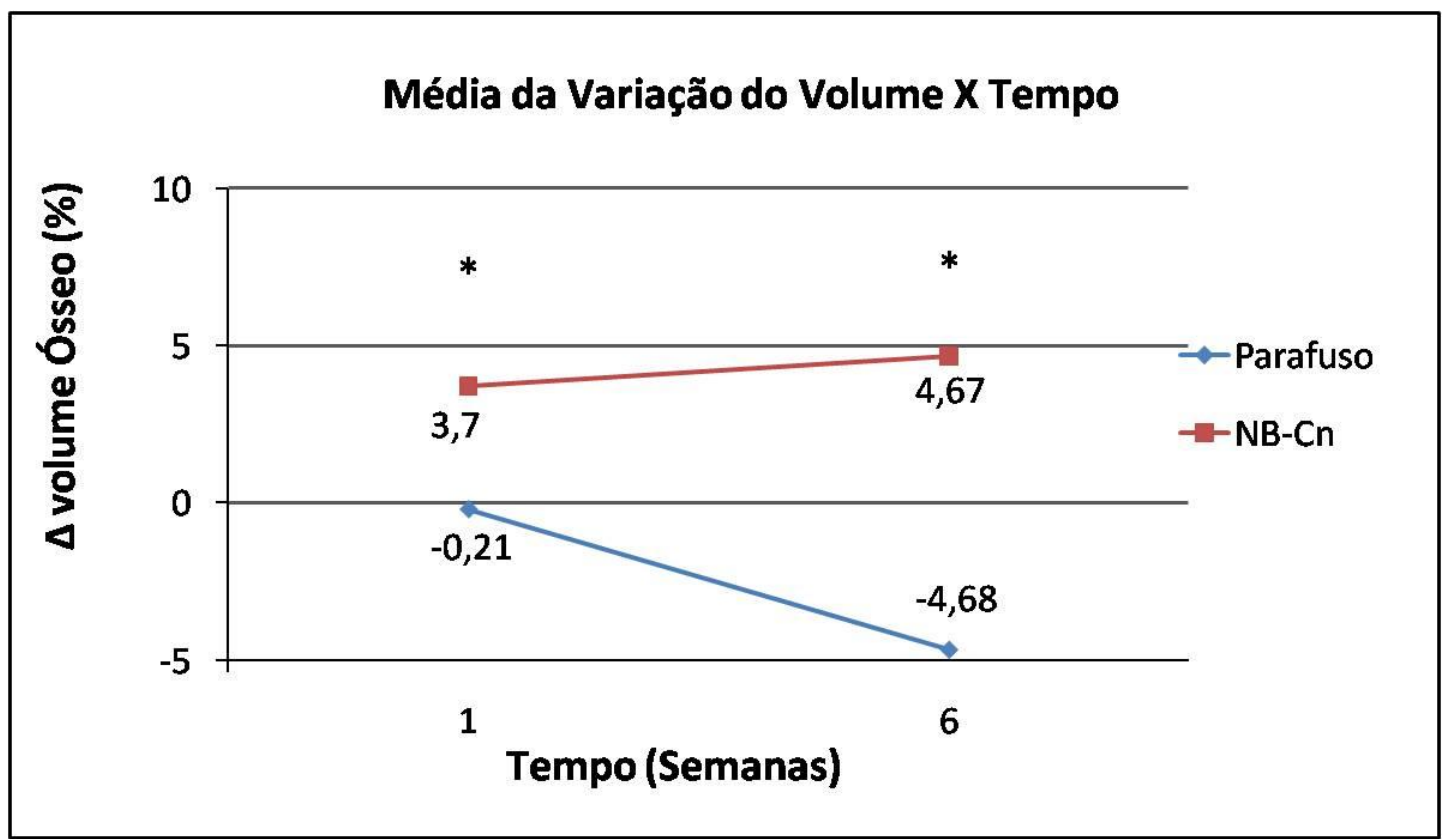

Gráfico 1 - Média da variação do volume dos enxertos (Volume no Sacrifício - Volume Inicial) para cada grupo estudado no período de 1 e 6 semanas. $*=$ Diferença estatística entre os grupos.

Tabela 3 - Intensidade de marcação para a proteína TRAP para ambos os tratamentos e nos dois tempos de sacrifício.

\begin{tabular}{|c|c|c|c|c|c|c|c|}
\hline \multirow[b]{2}{*}{ Tempo } & \multicolumn{3}{|c|}{ NB-Cn } & \multicolumn{3}{|c|}{ Parafuso } & \multirow{2}{*}{$\begin{array}{c}p(\text { entre } \\
\text { tratamentos })\end{array}$} \\
\hline & mediana & média & dp & mediana & média & dp & \\
\hline $1 \mathrm{sem}$ & 0,00 & 0,33 & 0,52 & 1,00 & 0,67 & 0,52 & $0,109 \mathrm{~ns}$ \\
\hline $6 \mathrm{sem}$ & 2,00 & 2,00 & 1,10 & 2,50 & 2,50 & 1,64 & $0,285 \mathrm{~ns}$ \\
\hline $\begin{array}{l}\mathrm{p} \text { (entre } \\
\text { tempos) }\end{array}$ & \multicolumn{3}{|c|}{$0,007 *$} & \multicolumn{3}{|c|}{$0,030 *$} & \\
\hline
\end{tabular}

